\title{
Antecedentes iconográficos de la imagen de la Virgen de Guadalupe
}

\begin{abstract}
$\mathrm{E}$ 15 de septiembre de 1556 el arzobispo de México, Alonso de Montúfar, predicó un sermón en la ermita del cerro del Tepeyac, situado al norte, en las inmediaciones de la ciudad de México, durante el cual exaltó diversos milagros realizados por la Virgen de Guadalupe. ${ }^{I}$ Francisco de Bustamante, el prior de la orden franciscana, no estuvo de acuerdo con lo dicho por Montúfar, por lo cual, tres días después, a su vez, abordó el tema en un sermón que predicó durante una misa solemne, en honor a la natividad de la Virgen, celebrada en el convento de San Francisco de México, en presencia del virrey, los miembros de la Real Audiencia, las máximas autoridades civiles y religiosas del virreinato, así como de una nutrida concurrencia de fieles.

Aunque no se conserva el sermón de Bustamante, se sabe cuál fue su contenido gracias a los testimonios de varias personas que lo escucharon. ${ }^{2}$ Sostuvo que el culto a la Virgen de Guadalupe, por ser muy reciente, carecía de un fundamento sólido, como, por ejemplo, era el caso de Nuestra Señora de Loreto; por lo cual ninguno de los milagros atribuidos a la imagen estaba comprobado y era reprobable la conducta de quienes los difundían; que la "invención” y "publicación” de dichos milagros constituía idolatría e iba contra
\end{abstract}

I. En el marco de este trabajo los términos Virgen de Guadalupe, Guadalupana, santuario de Guadalupe y Guadalupe como sitio geográfico, se refieren al caso mexicano. Cuando éstos mismos se refieren a la Virgen y al santuario espańol, se señala específicamente.

2. "Denuncias sobre la casa de nuestra señora de Guadalupe", en Testimonios históricos guadalupanos, comps. Ernesto de la Torre Villar y Ramiro Navarro de Anda (México: Fondo de Cultura Económica, I982), 43-I4I. 
las enseńanzas que los religiosos habían dado a los naturales; que las esperanzas de los indios que recurrían a la imagen en busca de ayuda resultaban burladas, lo cual ocasionaba que menguara su fe; que no debían adorarse imágenes de "palo y de piedra" o pintadas y que éstas, por sí solas, no podían obrar milagros; que la imagen de la Virgen de Guadalupe sólo era una representación de la Virgen celestial, pintada por un indio de nombre Marcos; que se extirpara entre los indios la creencia y práctica de adorar a la Virgen como si fuera Dios y se castigara con 100 o 200 azotes a la persona que había inventado los prodigios y a quienes los difundieran; que había incertidumbre respecto a la manera en que se gastaban las limosnas que recababa la ermita y que éstas debían destinarse a los pobres y al hospital de bubas; que el rey, como patrono de la Iglesia, debía poner remedio a tales abusos, "aunque el arzobispo dijese otra cosa”, y que si continuaba el culto a la imagen de Guadalupe, él dejaría de predicar a los indios, porque significaría retroceder en su evangelización. ${ }^{3}$

El arzobispo Montúfar, como principal impulsor del culto guadalupano y de los milagros atribuidos a la Virgen, se sintió atacado por Bustamante, por lo cual presentó una denuncia en su contra. Ésta dio lugar a una averiguación en la que testificaron nueve personas: tres clérigos, dos funcionarios de la Real Audiencia, un allegado a Montúfar y tres vecinos de la ciudad de México. ${ }^{4}$ Los testigos sostuvieron que el sermón de Bustamante había causado indignación entre la población, culparon al predicador de atentar en contra de la devoción a la Virgen de Guadalupe y proporcionaron información sobre el sermón, sobre la situación de la ermita, sobre la imagen y sobre el culto que se le tributaba.

Gracias a estos testimonios se sabe que en 1556 , unos 25 años después de la fundación de la ermita, el culto a la Virgen de Guadalupe se había extendido a todos los sectores de la población y ya no era privativo de los indios, como lo había sido al principio. Ricos y pobres de la ciudad de México y de las inme-

3. "Denuncias sobre la casa de nuestra señora de Guadalupe", en Testimonios históricos guadalupanos, 43-45.

4. Este proceso judicial consta de una denuncia en contra de Bustamante, de un cuestionario de trece preguntas elaborado para los testigos y de las declaraciones de nueve de ellos, entre quienes se encontraban varios personajes importantes, como el procurador de la Real Audiencia, Juan de Salazar; el bachiller Puebla, capellán del virrey; el abogado de la Real Audiencia, Francisco de Salazar, así como vecinos y clérigos. Esta averiguación generó una abundante documentación que da mucha luz sobre la situación de la ermita y el culto a la Virgen del Tepeyac a mediados del siglo XvI.

5. La leyenda sitúa la fundación de la ermita en I53I, fecha que parece verosímil, ya que coincide con la labor misional de los franciscanos, llevada a cabo en el altiplano central, en 
diaciones acudían los domingos y días festivos al Tepeyac a escuchar misa y a llevar ofrendas a la Virgen; con esto habían perdido la costumbre de ir a "las huertas", donde antaño buscaban esparcimiento en "placeres ilícitos", como el juego y los cortejos amorosos, con lo que "solían ofender a Dios" y "atentar en contra de las buenas costumbres". ${ }^{6}$ A la ermita llegaban asimismo numerosos peregrinos de diferentes lugares del reino, mismos que seguían la costumbre ancestral de acudir ahí para honrar a su diosa Tonantzin, cuyo culto ahora estaba fusionado con el de la Virgen María y personificado en la imagen que de ella se encontraba en la ermita. ${ }^{7}$

La atracción que visitantes y peregrinos sentían por la ermita se debía a los milagros atribuidos a la imagen de la Virgen, tales como haber curado enfermos, haber controlado la peste de I554, que causó miles de muertos, y haber salvado la vida al hijo del regidor de la ciudad, Antonio Carbajal, cuando se desbocó su caballo. ${ }^{8}$ Para obtener sus favores, los devotos ofrecían limosnas y penitencias a la Virgen: iban descalzos o recorrían de rodillas el trayecto de la puerta de entrada al altar mayor, y le ofrecían danzas y cantos. ${ }^{9}$

Ninguna de las personas que testificaron en el juicio en contra de Bustamante mencionó las apariciones de la Virgen a Juan Diego ni la milagrosa impresión de su imagen en el ayate del indio y nadie objetó que el franciscano hubiera atribuido el origen de la imagen a la mano del indio Marcos. Por esta razón y porque tampoco hay información sobre estos asuntos en otros documentos de la época, se puede concluir que, hacia mediados del siglo xvI, los devotos de la Virgen aceptaban el origen terrenal de la pintura.

El propósito del presente estudio no es abundar sobre estas cuestiones, que ya han sido abordadas por numerosos especialistas guadalupanos, sino indagar los antecedentes formales de la imagen de la Virgen de Guadalupe y examinar sus características iconográficas. Aunque la iconografía guadalupana

las inmediaciones de la ciudad de México. Véase Stafford Poole, Our Lady of Guadalupe: the Origins and Sources of a Mexican National Symbol, I53I-I797 (Tucson: University of Arizona Press, 1995), 26-33.

6. Testimonios de Francisco y de Juan de Salazar, "Denuncias sobre la casa de nuestra Señora de Guadalupe", 5I-59.

7. Poole, Our Lady of Guadalupe, 49-68; Jaime Cuadriello, Zodiaco mariano (México: Museo de la Basílica de Guadalupe, 2004).

8. Testimonio de Juan de Salazar, "Denuncias sobre la casa de nuestra Señora de Guadalupe", 5 .

9. Testimonio de Juan de Salazar, "Denuncias sobre la casa de nuestra Señora de Guadalupe", 52 . 
ha llamado la atención a diversos historiadores del arte - entre ellos Francisco de la Maza, Elisa Vargaslugo, Clara Bargellini, Jaime Cuadriello y Jeanette Favrot Peterson - la mayoría de los análisis se centra en las copias y composiciones pictóricas del siglo XVII en adelante, producidas a partir de la pintura original, ${ }^{\text {IO }}$ y sólo se ocupa la manera colateral de los antecedentes iconográficos de la imagen. ${ }^{\text {II }}$

\section{La Virgen de Guadalupe, una nueva imagen perteneciente a un modelo iconográfico del ámbito flamenco-alemán}

La pintura de la Virgen de Guadalupe se puede entender como original si partimos de la postura de que fue concebida en la Nueva España. Representa

Io. La primera copia de la imagen de la Guadalupana que se conoce es de Baltasar de Echave Orio y data de 1606 . A partir de ese momento proliferaron las réplicas, trasuntos y copias, así como pinturas en las que esta Virgen aparece rodeada de escenas de sus apariciones, entre otros. Para un análisis pormenorizado véase Jaime Cuadriello, Maravilla americana. Variantes de la iconografía guadalupana. Siglos XVII-XIX (Guadalajara: Patronato Cultural de Occidente, 1989).

II. Se han ocupado de la iconografía guadalupana los siguientes especialistas: Francisco de la Maza, El guadalupanismo mexicano (México: Tezontle/Fondo de Cultura Económica, I98I [1953]); Elisa Vargaslugo, "Apuntes sobre la pintura guadalupana en el siglo XvII", en Coloquio Internacional de Arte e Historia en Memoria de Juana Gutiérrez Haces. Amans artis, amans veritatis (México: Universidad Nacional Autónoma de México/Fomento Cultural Banamex, 20II), I87-205; Elisa Vargaslugo, "Algunas notas más sobre la iconografía guadalupana", Anales del Instituto de Investigaciones Estéticas XV, núm. 60 (1989): 59-66; Elisa Vargaslugo, "Iconología guadalupana", Imágenes guadalupanas cuatro siglos (México: Centro Cultural/Arte Contemporáneo, 1988), 57-178; Cuadriello, Maravilla americana; Clara Bargellini, "Una Guadalupana de José de Alcíbar", en De arquitectura, pintura y otras artes. Homenaje a Elisa Vargaslugo (México: Universidad Nacional Autónoma de México, 2004), 135-154; Clara Bargellini, "The Colors of the Virgin of Guadalupe", en Colors Between Two Worlds: The Florentine Codex of Bernardino de Sahagun, eds. Gerhard Wolf y Joseph Connors, The Harvard University Center for Italian Renaissance Studies 28 (Florencia: Kuntshistorisches Institut in Florenz-Max-Planck-Institut y Villa I Tati, 20II), 3-25; Clara Bargellini, "The Virgin of Guadalupe: A Painting of New Spain", en http://ism. yale.edu/sites/default/files/files/The\%20Virgin\%20of\%20Guadalupe.pdf, consultado el 25 de marzo de 20I5; y Clara Bargellini, "Originality and Invention in The Painting of New Spain", en Painting a New World. Mexican Art and Live. IS2I-I82I, eds. Donna Pierce, Rogelio Ruiz Gomar et al. (Austin: University of Texas Press, 2004), 79-9I; y Jeanette Favrot Peterson, "Creating the Virgin of Guadalupe: The Cloth, The Artist, and Sources in Sixteenth-Century New Spain", The Americas 6I, núm. 4 (abril 2005): 57I-610; Jeanette Favrot Peterson, Visualizing Guadalupe. From Black Madonna to Queen of Americas (Austin: University of Texas Press, 20I4), I2O-I23. 
I. Anónimo, Virgen con el Niño, siglo XII. Santuario de Guadalupe, Extremadura, España. Tomada de Sebastián García Rodríguez y Francisco Tejada Vizuete, El camarin de Guadalupe. Historia y esplendor (Madrid: Comunidad Franciscana de Guadalupe/ Ediciones Guadalupe, 1996), 79.

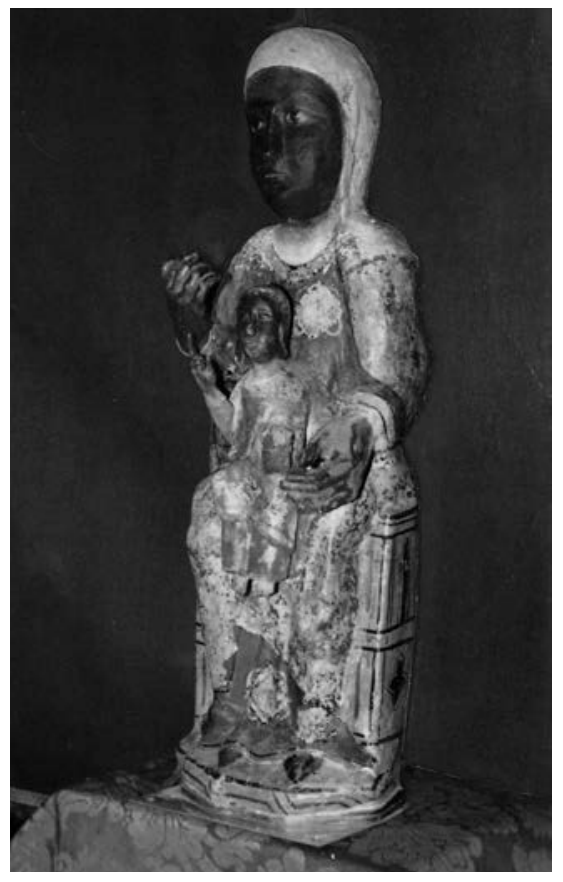

a la Virgen María como "madre de Dios", en abstracto, sin aludir a advocación alguna, ya que fue bajo este concepto que se fundó la primera ermita del Tepeyac en la cual se colocó la pintura. ${ }^{\mathrm{I2}}$

A diferencia de muchas otras imágenes de culto introducidas a la Nueva España en el siglo xvi como las de nuestras señoras de los Remedios, del Rosario y del Populo, la imagen de la Virgen mexicana es independiente de la Virgen de Guadalupe del santuario español de Extremadura, a pesar de que lleve su nombre, ya que esta última es una talla en madera de ébano, en estilo románico, con características formales muy diferentes (fig. I). Ciertamente, como señaló en su momento Manuel Toussaint ${ }^{\mathrm{I} 3}$ y hoy día sostiene, entre otros el historiador del santuario, fray Sebastián García, ${ }^{14}$ sí se puede encontrar algún

I2. Testimonio de Francisco de Salazar, "Denuncia sobre la casa de Nuestra Señora de Guadalupe", 58.

13. Manuel Toussaint, Pintura colonial en México (México: Universidad Nacional Autónoma de México-Instituto de Investigaciones Estéticas, 1982), 24.

I4. Entrevista a Sebastián García, en Sanjuana Martínez y Rodrigo Vara, "Las guadalu- 
parecido con la imagen de la Virgen del Coro (fig. 17), del mismo santuario extremeño. No obstante, la Guadalupana mexicana no es su réplica (fig. 2). Las similitudes formales que existen entre las dos imágenes se deben a que ambas pertenecen a la misma tradición iconográfica, pero sus diferencias permiten afirmar que la española no fue el modelo de la mexicana: la extremeña tiene Niño y la mexicana no; difieren en cuanto a las proporciones del cuerpo de la Virgen, la posición de la cabeza, la mirada, los rasgos faciales, la posición de las manos, los pliegues de la túnica y del manto, la forma de la mandorla ${ }^{15}$ y la figura del ángel y sus alas. La independencia de los dos santuarios guadalupanos fue reconocida en 1574 por fray Diego de Santa María, uno de los monjes jerónimos custodios del santuario extremeño, quien llegó a la Nueva Espańa con la encomienda de canalizar una parte de las limosnas hechas a la Virgen mexicana hacia la casa matriz y tuvo que regresar a Espańa con las manos vacías. ${ }^{16}$

Si bien la imagen de la Guadalupana se puede entender como original por ser novohispana, recoge características iconográficas que obedecieron a cánones netamente europeos. Considero que, en particular, derivan de un modelo de imagen denominado mulier amicta sole (la mujer rodeada de sol), proveniente de los Países Bajos y de Alemania. ${ }^{17}$

Este modelo procede conceptualmente de la descripción que hace san Juan de la mujer celestial, en el Apocalipsis del Nuevo Testamento: "una mujer, vestida de sol, con la luna bajo sus pies y una corona de doce estrellas sobre su cabeza" (Apocalipsis I2,I). ${ }^{18}$ La mujer celestial se identificó con la Virgen María dado el papel protagónico que ella desempeñó en la lucha cósmica entre el bien y el mal y el hecho de que diera a luz a "un hijo varón, el que ha de regir a todas las naciones con el cetro de hierro" (Apocalipsis I2,5).

panas. La mexicana, hija de la española”, Proceso, núm. I4I4, 7 de diciembre de 2003, http:// www.lamujerdepurpura.com/2009/12/la-Virgen-de-guadalupe-de-mexico-copia.html, consultado el ro junio de 2014 .

I5. El término mandorla (del italiano, "almendra") define el haz de luz que envuelve a la Virgen o a otra figura sagrada.

I6. Diego de Santa María, "Dos cartas de fray Diego de Santa María al rey de España, I574 y 1575 ", en Documentos guadalupanos. Un estudio sobre las fuentes de información tempranas en torno a las mariofanias en el Tepeyac, comp. Xavier Noguez (México: El Colegio Mexiquense/ Fondo de Cultura Económica, 1993), 229-236.

17. Ewald Vetter, "Virgo in sole", en Homenaje a Johannes Vincke, vol. I (Madrid: Consejo Superior de Investigaciones Científicas, 1963), 367-420.

18. Favrot Peterson, Visualizing Guadalupe, I2O-I23. 
El modelo de la mulier amicta sole, que coexistió junto con otras maneras de representar a la Virgen, se utilizó ampliamente en la imaginería religiosa desde la Edad Media, primero en Flandes y Alemania y posteriormente en todo el mundo católico. ${ }^{\text {I9 }}$ Se plasmó en dibujos, miniaturas y pinturas al óleo, tallas en madera y esculturas y, a partir del siglo xv, se reprodujo masivamente en xilografías y grabados en metal.

Los tres principales elementos iconográficos que conforman el modelo de la mulier amicta sole son: la luna creciente bajo sus pies, los rayos del sol en forma de mandorla que rodean su cuerpo y la corona de 12 estrellas sobre su cabeza.

Este estudio se basa en el análisis de un corpus de grabados, pertenecientes al ámbito flamenco-alemán, que presentan los tres elementos iconográficos que integran el modelo. ${ }^{20}$ Todos ellos datan del siglo $\mathrm{xv}$ y de las tres primeras décadas del siglo XVI, es decir, son anteriores a la realización de la obra de la Guadalupana. En su mayoría se trata de estampas sueltas, cuyo tamaño fluctúa entre $4 \mathrm{I} \times 29$ centímetros, la más grande, y 3.5 × 2.8, la más pequeña, y en menor cantidad se cuentan imágenes impresas en libros. La mayor parte son xilografías, aunque para otras se utilizaron diferentes técnicas, como punta seca y grabado en metal. Del total, la mayoría son anónimas y algunas están firmadas: éstas son de la autoría de Alberto Durero; de Israhel van Meckenem; de Martin Schongauer y de Albrecht Altdorfer. Cuatro artistas firman con rúbricas; la obra con las iniciales "IW" ha sido atribuida por Franz Winzinger

I9. Vetter, "Virgo in sole". El modelo subsiste actualmente con las características iconográficas de la Inmaculada Concepción, establecidas en el siglo XVII.

20. Las obras pertenecen a más de $\mathrm{I} 4 \mathrm{O}$ repositorios (bibliotecas, archivos, museos, etcétera) de Alemania, Austria, Bélgica, los Países Bajos, Italia, Francia, Inglaterra, Estados Unidos, entre otros. Algunos catálogos de gran utilidad son: el suplemento número I64 de The German Single-Leaf Woodcut before I500, de The Illustrated Bartsch, ed. Richard S. Field (Nueva York: Abaris Books, 1992), I07-196; The German and Netherlandish Masters of the Fifteenth and Sixteenth Centuries, de The Illustrated Bartsch, ed. Martha Wolff, suplemento 23 (Nueva York: Abaris Books, 1992); el catálogo de Jan van der Stock, Early Prints in the Royal Library of Belgium. The Catalogue (Turnhout: Brepols, 2002); la edición Grabados alemanes de la Biblioteca Nacional (siglos XV-XVI), ed. Concepción Huidobro Salas, 2 vols. (Madrid: Ministerio de Educación y Cultura de Madrid, I997), y el primer volumen del estudio de Adrien Jean Joseph Delen, Histoire de la gravure dans les ancients Pays-Bas et dans les provinces Belges des origines jusqu'a la fin du XVIIIe siecle, vol. I, Des origines a I50o (París y Bruselas: Libraire Nationale d'Art et d'Histoire, 1924). Asimismo fueron de gran utilidad las obras monográficas sobre los artistas de la época. 
al maestro de Mühldorf. ${ }^{21}$ Una obra impresa en el libro Contra Alchonarum, editado en 1533 , se le atribuye a Anton Woensam, ${ }^{22}$ y La Virgen con el Niño, rodeada de ángeles músicos, a Heinrich Steiner.

La complejidad compositiva y la calidad artística de las obras que integran esta selección son variables. Algunas, especialmente las de formato muy pequeño, son composiciones sencillas y su realización es bastante burda, mientras que otras denotan un gran dominio de la técnica y un refinamiento en cuanto a la forma.

El prototipo de la mulier amicta sole se utilizó principalmente para representar a la Virgen María como madre de Dios, con el Niño en brazos, pero, asimismo, se adaptó mediante la añadidura o supresión de elementos para figurar advocaciones marianas específicas. Como Virgen de la Ascención se representó sin el Niño, rodeada de ángeles que la levantan en vilo hacia el cielo; como Virgen del Rosario se le dotó de ángeles o fieles portando rosarios (corpus ilustrado núms. I, 2, 3, 4); como Tota pulchra ${ }^{23}$ se le rodeó de los signos de la letanía lauretana, y para figurar a la mujer del Apocalipsis se incluyó al demonio —en forma de dragón de siete cabezas o de serpiente_- a los pies de la Virgen. En muchos casos se añadieron motivos en las áreas externas a las mandorlas: ángeles en vuelo, con cartelas, coronando a la Virgen (corpus ilustrado, núms. 5-7); o con instrumentos musicales o pasionarios (corpus ilustrado, núms. 8-Io); aves y flores; los cuatro evangelistas (corpus ilustrado, núms. II y I2); santos, frailes, monjas y otros personajes orando (corpus ilustrado, núms. I3-I8).

Puesto que la imagen de la Virgen de Guadalupe forma parte de la tradición iconográfica del norte de Europa presenta similitudes con muchas de las obras incluidas en este estudio. ${ }^{24}$ Del corpus de imágenes he seleccionado I3 para establecer comparaciones entre ellas: nueve corresponden al siglo xv y cuatro a las dos primeras décadas del siglo Xvi. Del siglo XV datan las siguientes xilografías anónimas que identifico añadiendo el repositorio donde se encuentran: La Virgen en la gloria, de Berlín (fig. 3); La asunción de la Virgen, de Bruselas

2I. Max Geisberg, The German Single-Leaf Woodcut: I500-I550, vol. IV (Nueva York: Hacker Art Books, 1974), y Franz Winzinger, "Unbekannte Werke des Meisters von Mühldorf”, Zeitschrift des Deutschen Vereins für Kunstwissenschaft, vol. 22 (1968), 2I.

22. Grabados alemanes de la Biblioteca Nacional, I5II.

23. El término Tota pulchra proviene de un antiguo rezo del siglo xiv, basado en El Cantar de los Cantares, que inicia de la siguiente manera: "Tota pulchra es, Maria, / et macula originalis non est in te", que significa: "Eres toda hermosa, María, / y no hay mancha original en ti". 24. The German Single-Leaf Woodcut before 1500, de The Illustrated Bartsch, I07-196. 
(fig. 4); La Virgen con el Niño, inserta mediante collage en un libro manuscrito de oraciones flamenco-alemán-francés (fig. 5), La Virgen con santa Catarina y santa Bárbara del mencionado libro (fig. 6), y La Virgen con el Niño, acompañada de cuatro ángeles, de Berlín (fig. 7). Otras importantes imágenes son: La Virgen del Rosario, de Israhel van Meckenem (fig. 8); La Virgen con el Niño, de I490, de Martin Schongauer (fig. 9), y San Juan escribe el Apocalipsis en la isla de Patmos de este mismo autor (fig. Io). De principios del siglo XVI se incluyeron las siguientes obras: La Virgen con el Niño (I508), de Alberto Durero (fig. II); La Virgen con el Niño (I5I5), firmada como IW (fig. I2); la xilografía de La Virgen con el Niño, de Anton Woensam, impresa en el libro Contra alchonarum, editado en $\mathrm{I} 533$ (fig. I3), y La Virgen con el Niño, rodeada de ángeles músicos, de Heinrich Steiner (fig. I4).

Uno de los principales elementos del modelo que distingue a la imagen de la Virgen de Guadalupe de otras imágenes marianas canónicas del ámbito hispánico es la mandorla. Este elemento se encuentra de manera parecida en las estampas xilográficas más antiguas del siglo Xv, como en La Virgen con el Niño acompañada de cuatro ángeles (fig. 7); en la de Israhel van Meckenem sobre la Virgen del Rosario (fig. 8); en el grabado sobre San Juan escribe el Apocalipsis, de Martin Schongauer (fig. IO), y en las imágenes tempranas del siglo Xvi de Alberto Durero (fig. II), el maestro de Mühldorf (fig. I2), Anton Woensam (fig. 13) y Heinrich Steiner (fig. I4).

En la mandorla de la Guadalupana alternan un rayo ondulante y uno recto, como se advierte también en la estampa pegada mediante collage en un libro de oraciones flamenco, en La Virgen con el Niño acompañada de cuatro ángeles (fig. 7) y en la estampa xilográfica de Heinrich Steiner (fig. I4), entre muchos otros grabados de la época como por ejemplo La Virgen con el Niño (fig. 5). Sin embargo, los rayos de la Guadalupana son más finos y asemejan la manera que se impuso a partir del siglo xvi, cuando se refinó la técnica del grabado en madera y se expandió el hecho de figurar rayos rectilíneos delgados y paralelos en metal, como aparecen, por ejemplo, en las obras de Durero (corpus ilustrado, núms. 19, 20 y 2I); así como en la representación antes mencionada de San Juan escribe el Apocalipsis, de Schongauer (fig. ro).

La mandorla de la Virgen de Guadalupe está rodeada por nubes, un elemento que se observa en muchas obras del modelo. Se encuentran con la presencia de ángeles en el grabado de Israhel van Meckenem del último tercio del siglo Xv (fig. 8), en la estampa xilográfica de principios del siglo xvi, de Heinrich Steiner (fig. I4) y en la del maestro de Mühldorf, que incluye cuatro ángeles músicos, 


\section{$\oplus$}

DOI: http://dx.doi.org/10.22201/iie.18703062e.2015.107.2558

I82

GISELA VON WOBESER

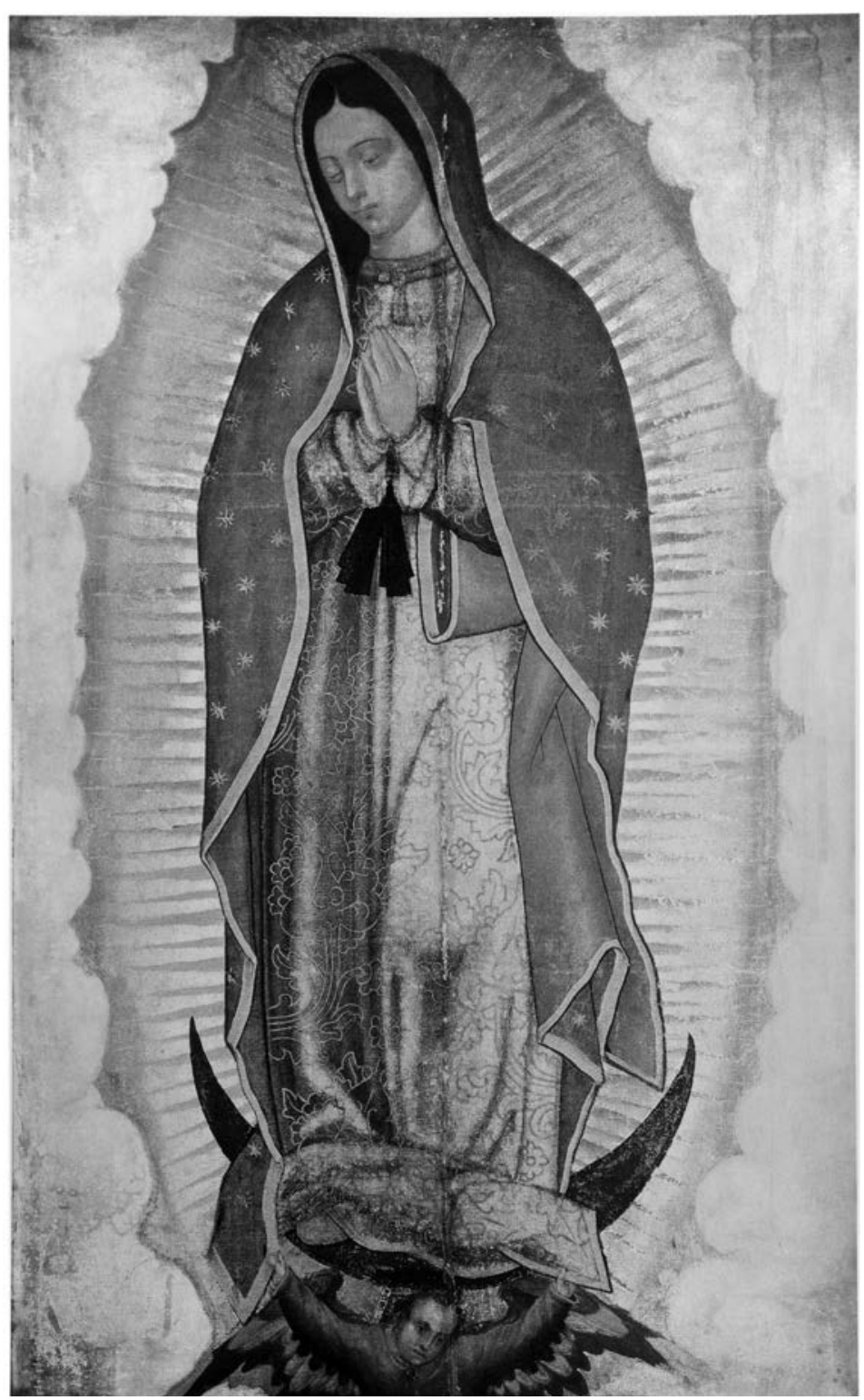

$\oplus$

2. Anónimo, Virgen de Guadalupe, siglo xvi. D.R.@ Archivo del Museo de la Basílica de Guadalupe, ciudad de México. 


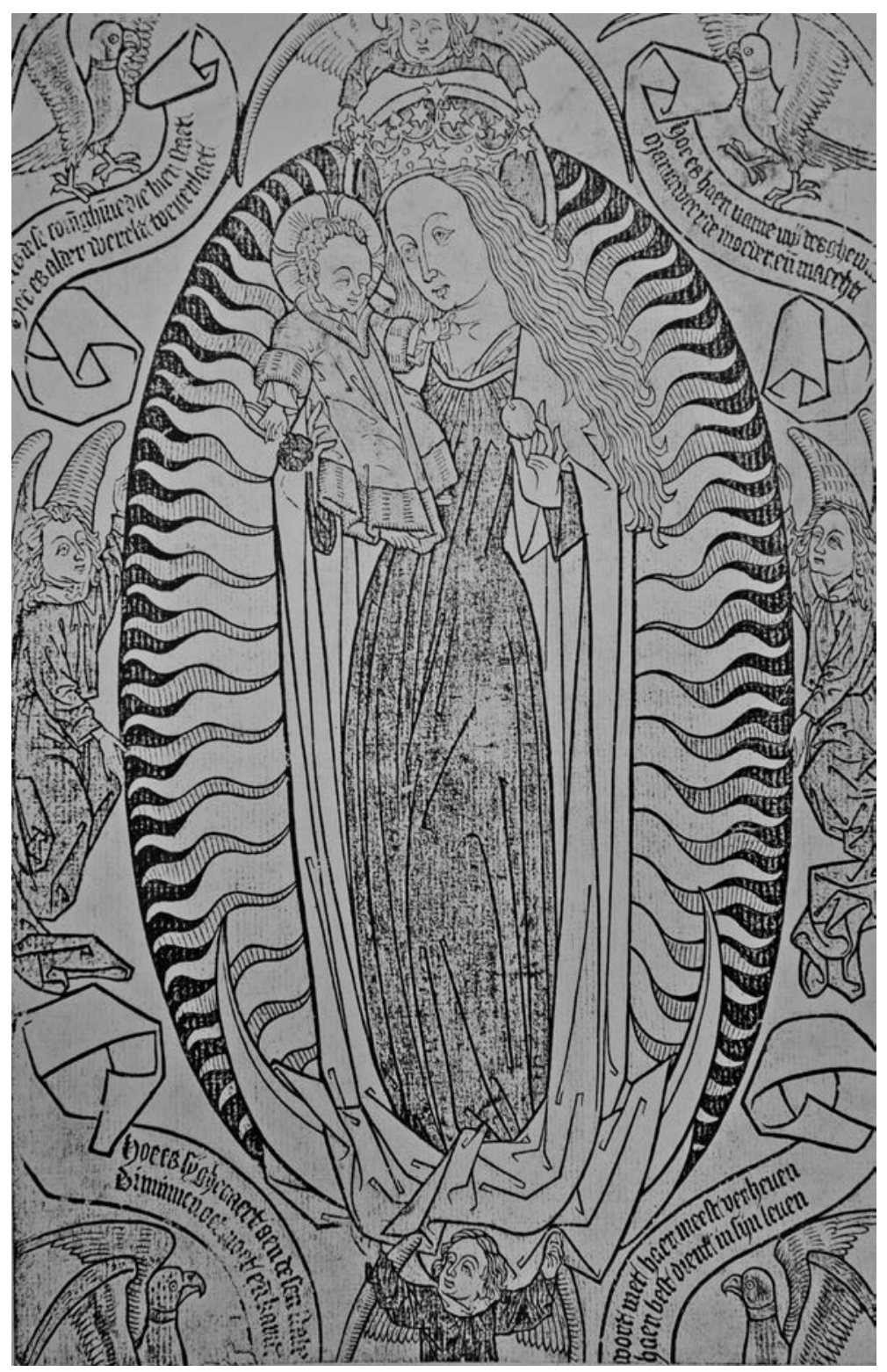

$\oplus$

3. Anónimo, La Virgen en la gloria, de Berlín, xilografía, ca. I420. Colección Fotográfica del Warburg Institute, Londres. 


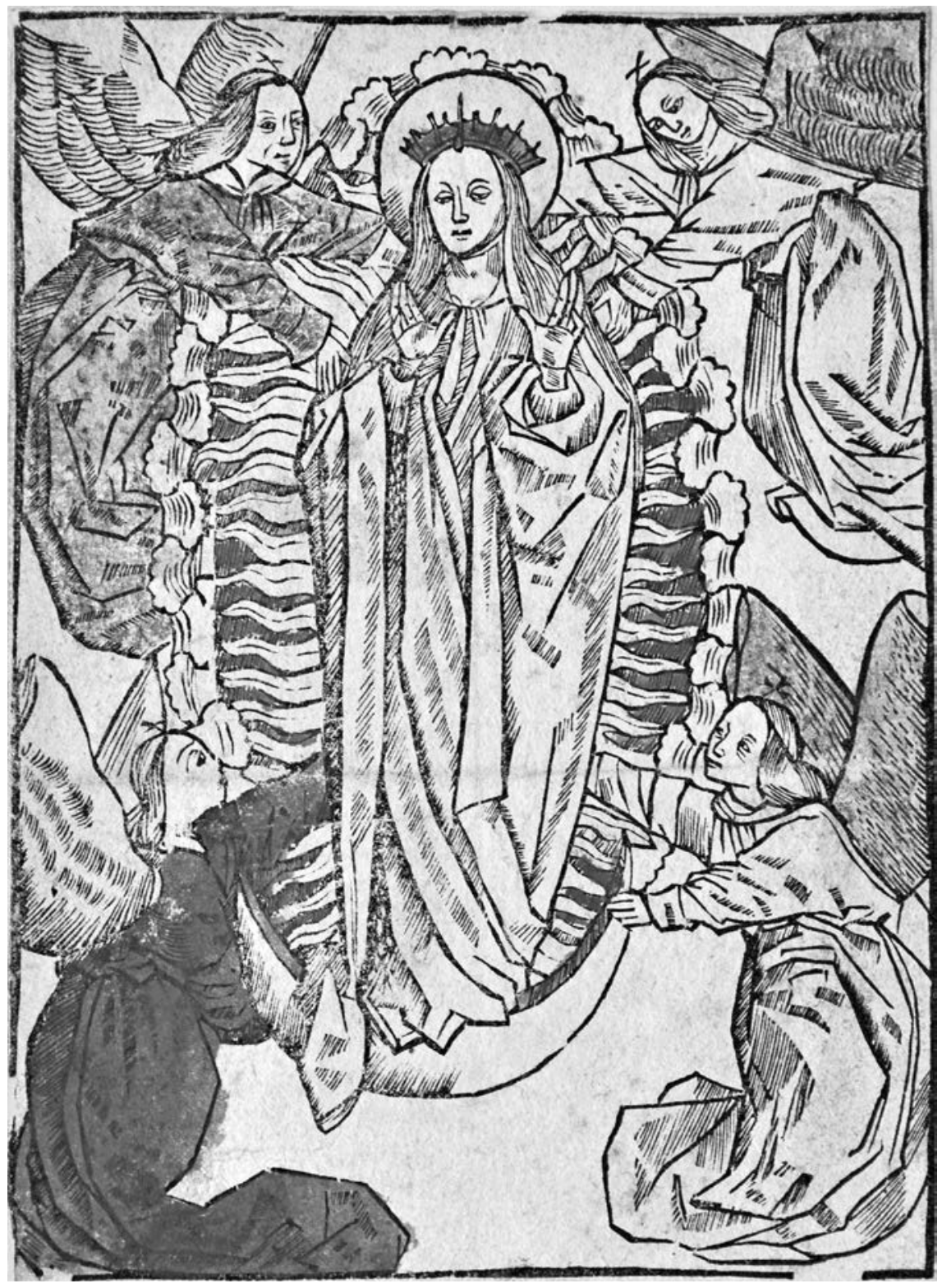

$\oplus$

4. Anónimo, La asunción de la Virgen, grabado coloreado, siglo xv. Biblioteca Real de Bruselas, Gabinete de Estampas. 
colocados en cada una de las esquinas de la composición (fig. I2). En los dos últimos grabados los ángeles ocupan las cuatro esquinas del mismo, lo cual obligó a alterar la mandorla en los extremos superiores e inferiores.

La postura de la Virgen de Guadalupe, erguida sobre una luna creciente, coincide con la mayoría de obras que aquí presento (corpus ilustrado, núms. 22-32). ${ }^{25}$ La manera como apoya la Guadalupana su peso en la pierna derecha y mantiene la izquierda flexionada, movimiento que se proyecta sobre la túnica y que motiva una ligera torsión del cuerpo y cara hacia la derecha, se observa en la obra de Woensam (fig. I3), en la estampa de Steiner (fig. I4), en la que está inserta en un libro de oraciones datada hacia I500 (fig. 5) y en la anónima de la Virgen en la gloria (fig. 3), entre otros. En todos los casos la Virgen viste túnica y capa, que llegan hasta sus pies y se proyectan encima de la luna creciente. En algunas obras, la tela de estas prendas es tan abundante que se desborda sobre la luna creciente y la cubre parcialmente, tal y como se observa en la Virgen en la gloria, de Berlín (fig. 3), y en la estampa del libro de oraciones (fig. 5). Asimismo, hay coincidencia en varias imágenes respecto a que la Virgen lleva recogido el manto bajo el brazo izquierdo, como por ejemplo en la obra de Steiner (fig. I4), y en el grabado del libro de oraciones (fig. 5), donde se asoman las mangas largas de la túnica bajo el manto, a la altura de los puños. Los pliegues angulosos que forman la túnica y el manto en sus extremidades y que se proyectan hacia la luna creciente y fuera de ella son característicos de estos modelos.

La punta afilada del zapato de la Guadalupana que se asoma bajo su túnica merece mención, pues es similar a la reproducción xilográfica del libro Contra alchonarum (editado en I533), atribuida a Anton Woensam (fig. 13).

La corona que portaba inicialmente la Virgen de Guadalupe sobre la cabeza — misma que sólo puede apreciarse en réplicas del original del periodo virreinal y del siglo xix, porque en 1895 fue borrada por órdenes del abad Plancarte, con motivo de la coronación de la Virgen de Guadalupe $-{ }^{26}$ destaca por su

\footnotetext{
25. Algunos artistas llegaron a representar a la Virgen sentada sobre la luna creciente, como lo hizo Alberto Durero en la xilografía Virgen sentada sobre una luna creciente, de 1504 (basada en una obra de Martin Schongauer). Véase Grabados alemanes de la Biblioteca Nacional (n. 20), número de inventario 29805. Otros artistas conservan la luna creciente, aunque sólo representen el busto de la Virgen. Véase The German Single-Leaf Woodcuts before I50o, de The Illustrated Bartsch, 73, 74 y 77, y La Virgen de la Peregrinación con rosario, del maestro Adalbert von Sachsen, en el claustro de la catedral de Mainz, Alemania.

26. El pintor que realizó la adaptación fue José Salomé Pina. Jaime Cuadriello, "Zodiaco mariano. Una alegoría de Miguel Cabrera”, en Zodiaco mariano. 250 años de la declaración
} 
originalidad y sencillez, ya que entre las imágenes correspondientes al modelo que he analizado no encontré ninguna parecida: únicamente consta de una base circular, sobre la cual están montados unos picos (fig. I5). Sin embargo, la corona es el elemento más variable en la iconografía flamenco-alemana, ya que hay innumerables formas de representarla. Se tiene la corona con las estrellas incorporadas (corpus ilustrado, núms. 33-37), en otros casos la Virgen únicamente porta una corona imperial sin estrellas (corpus ilustrado, núms. 38-43) y hay imágenes en las que incluso se representó sin corona, sin estrellas o sin ambas (corpus ilustrado, núms. 44-47).

Otro elemento que caracteriza a la Virgen de Guadalupe son las estrellas adheridas al manto, cuyo número supera por mucho las I2 mencionadas en el Apocalipsis. El ejemplo más recurrente es el grabado del artista flamenco Samuel Stradanus (fig. I6). Además he encontrado este motivo iconográfico en otras obras de épocas posteriores: un grabado del siglo XVII denominado Regis ad exemplum, diseñado por I. B. van Heild y realizado por R. Collin, perteneciente al Gabinete de Estampas de Bruselas, y en la imagen de la talla de madera policromada de la Virgen del coro del santuario de Guadalupe (fig. I7). Esta última es una pieza que data del siglo Xvi, pero las estrellas del manto no son originales sino que se ańadieron en la restauración que Manuel de Lara Churriguera llevó a cabo en $\mathbf{1 7 4 3}$, al parecer con la intención de que la Virgen de Extremadura se pareciera a la Virgen de Guadalupe mexicana. ${ }^{27}$

Por último, cabe señalar que la representación de la Virgen de Guadalupe, asimismo, comparte rasgos comunes con muchas imágenes marianas realizadas después de I530. Esto se debe a que el modelo se mantuvo vigente mediante la reimpresión de placas antiguas, así como por medio de la creación de nuevas obras, entre ellas la de la Virgen como Inmaculada Concepción, misma que se normalizó en el siglo Xvir. Esto último ha motivado a que muchos clérigos novohispanos de los siglos XVII y XVIII hayan considerado a la Virgen de Guadalupe como una Inmaculada Concepción. ${ }^{28}$

pontificia de María de Guadalupe como patrona de México (México: Museo de la Basílica de Guadalupe/Museo Soumaya, 2004), 2I-28.

27. Favrot Peterson, Visualizing Guadalupe, I3I.

28. Alicia Mayer, Flor de primavera mexicana. La Virgen de Guadalupe en los sermones novohispanos (México: Universidad Nacional Autónoma de México, 20I0), IO2-IIO; Jaime Cuadriello, "Virgo Potens. La Inmaculada Concepción en los imaginarios del mundo hispánico", en Pintura de los reinos. Identidades compartidas. Territorios del mundo hispánico. Siglos XVI-XVIII, coord. Juana Gutiérrez Haces, vol. 2 (México: Grupo Financiero Banamex, 2009), II69-I263. 
5. Anónimo, La Virgen con el Niño, estampa inserta en un libro de oraciones flamencoalemán-francés, ca. I500. Biblioteca Real de Bruselas, Gabinete de Estampas.

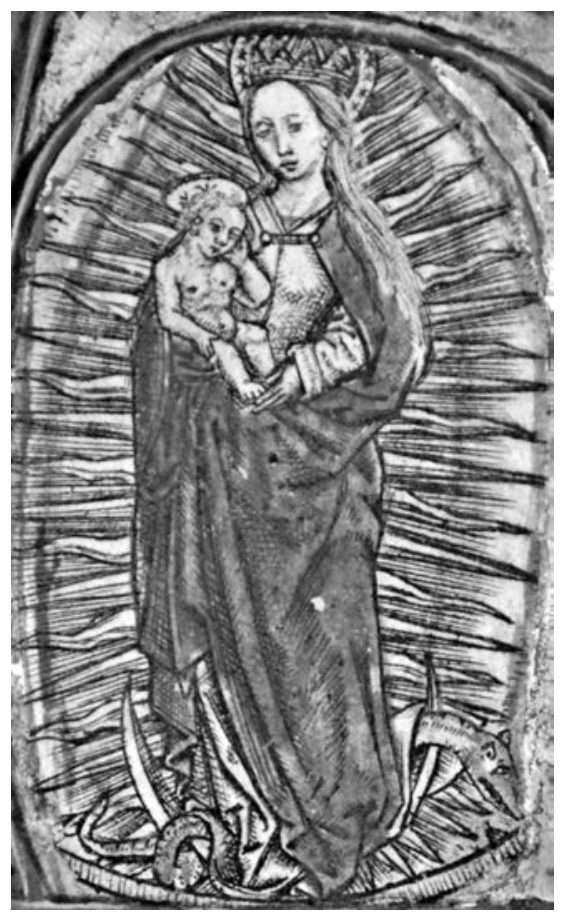

La Virgen en la gloria de Berlin, probable fuente para la imagen de la Virgen de Guadalupe

Entre las obras que presentan semejanzas con la pintura de la Virgen de Guadalupe quiero destacar la ya mencionada xilografía anónima conocida como $\mathrm{La}$ Virgen en la gloria, de Berlín (fig. 3) como posible fuente utilizada por el pintor Marcos. Representa a la Virgen coronada, con el Niño en el brazo derecho y una manzana en la mano izquierda. Su figura está rodeada por una mandorla con rayos flamígeros, custodiada por cuatro ángeles, uno a sus pies, que hace las veces de peana, dos a sus costados y uno más sobre su cabeza, el cual la está coronando. En los cuatro extremos tiene palomas que sostienen filacterias con inscripciones en lengua flamenca, que traducidas dicen lo siguiente: “¿Quién es esta reina? El consuelo del mundo./ Dime ¡cuál es su nombre? 


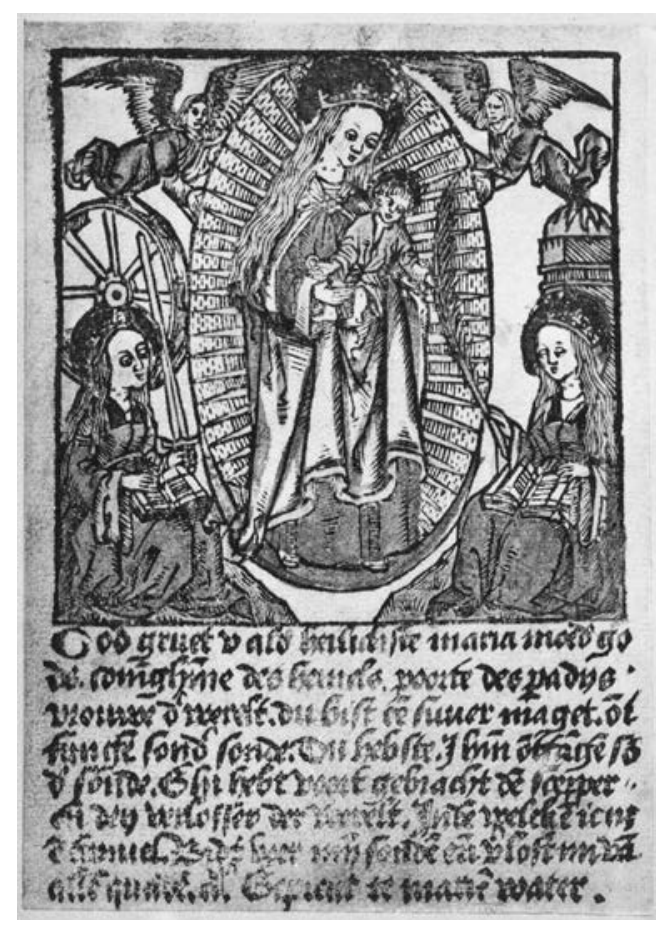

6. Anónimo, La Virgen con santa Catarina y santa Bárbara, estampa inserta en un libro de oraciones flamenco-alemán-francés, ca. I500. Colección Fotográfica del Warburg Institute, Londres.

María, madre y Virgen./ ¿Cómo obtuvo tanta gloria? Por su caridad y humildad./ ¿Cómo se podrá llegar a ella? Invocándola o imitándola”. ${ }^{29}$

Las formas dialectales de estas inscripciones indican como lugar de origen de la estampa los Países Bajos meridionales, específicamente la región de Brabante, según opinión del R. Berdenyen..$^{\circ}$ Ella data de los orígenes de la invención de la xilografía y ha sido fechada hacia I420. ${ }^{31}$ Pertenece a la época más gloriosa del grabado flamenco, y se considera entre las obras más perfectas de la gráfica flamenca. ${ }^{32}$

La pintura de la Virgen de Guadalupe coincide en sus trazos principales con los del grabado de La Virgen en la gloria de Berlín (véanse figs. 2 y 3),

29. Para la reproducción del grabado y la transcripción de la filacteria véase Delen, Histoire de la gravure dans les anciens Pays-Bas, 44-46.

30. Citado por Delen, Histoire de la gravure dans les anciens Pays-Bas, 44.

3I. El grabado más antiguo fechado es el de la Virgen de Bruselas, que data de I4I8.

32. Delen, Histoire de la gravure dans les anciens Pays-Bas, 44. 


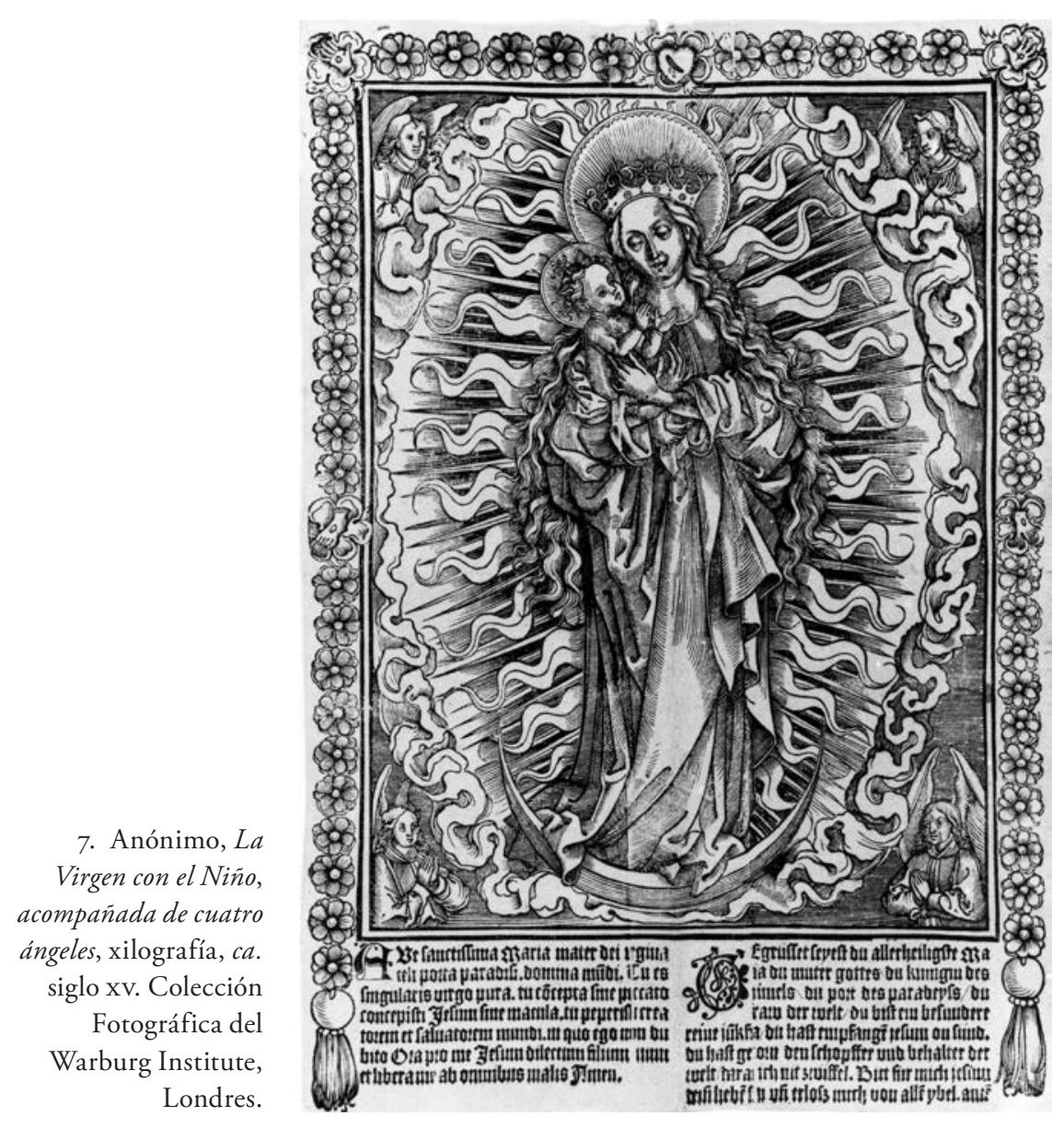

como se advierte en los perfiles negros que delimitan los contornos de la imagen guadalupana. En ambos casos la figura de la Virgen está rodeada por una mandorla que forma un óvalo casi perfecto; en la Guadalupana está delineada y los rayos de luz están alternados; en el de la flamenca varían, uno liso y uno rayado, y en el de la mexicana, uno recto y uno flamígero. A su vez, las dos obras sitúan a la Virgen en el centro de la composición y comparten la postura - la pierna izquierda ligeramente flexionada que produce el marcado pliegue en la túnica a la altura de la rodilla izquierda, apoyada en una luna 


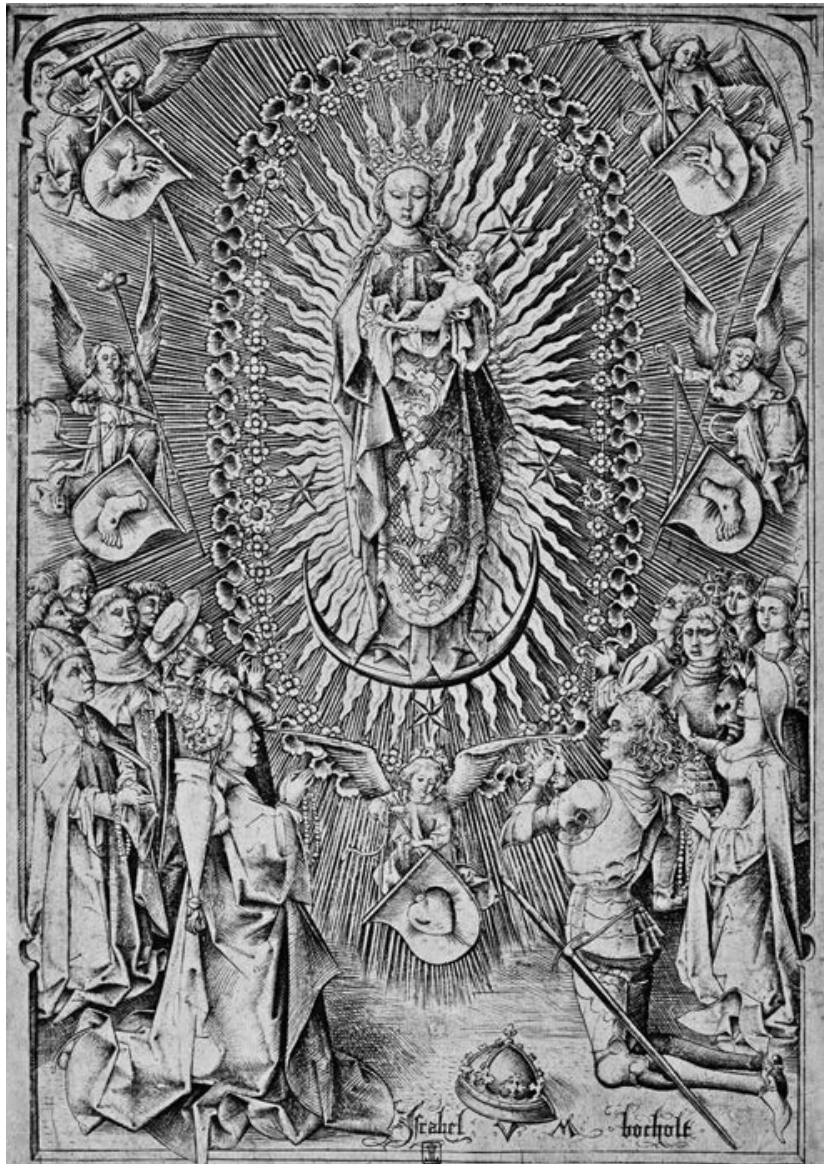

$\oplus$
8. Israhel van Meckenem, $\mathrm{La}$ Virgen del Rosario, grabado, último tercio del siglo xv. Biblioteca Real de Bruselas, Gabinete de Estampas.

creciente. Otras coincidencias radican en que en ambas imágenes la túnica muestra una cinta a la altura del cuello, las mangas largas se asoman entre el manto y llegan hasta los puños y el manto lo tiene recogido la Virgen bajo el brazo izquierdo. También hay similitud en la ubicación de la mano izquierda de la Virgen, aunque en el caso de la mexicana está unida con la mano derecha, y en el de la flamenca, sostiene una manzana.

La forma de la cabeza de la Virgen y su ligera inclinación hacia el lado derecho, con la barbilla recogida, son otras correspondencias entre el modelo y la Virgen guadalupana: la boca pequeńa, con el labio inferior más protuberan- 
9. Martin Schongauer, La Virgen con el Niño, grabado, ca. I490. Rijksmuseum, Ámsterdam, RP-P-OB-IO43.

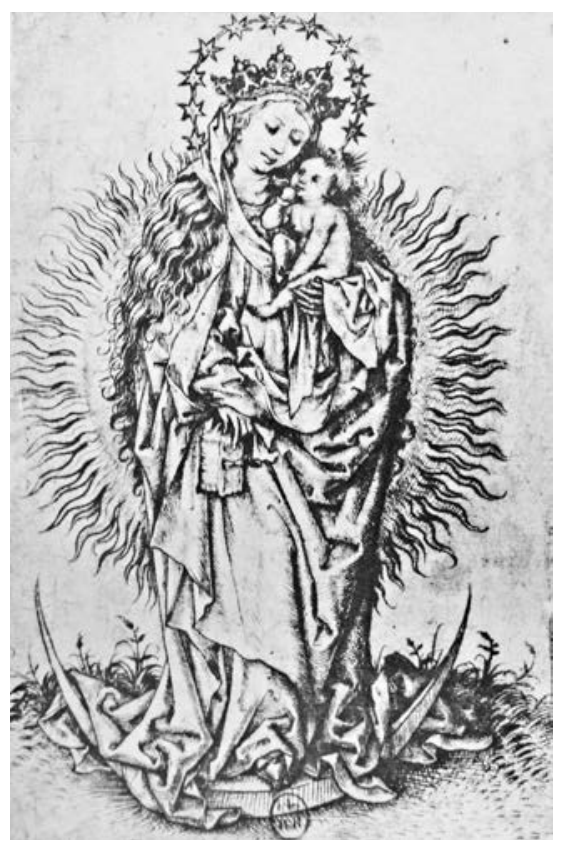

te que el superior; la nariz recta, cuyo lado izquierdo se proyecta en una línea hasta la ceja izquierda, y la forma de los ojos.

El ángel, que se encuentra al pie de la Virgen y que cumple la función de peana, es similar en ambas imágenes en cuanto a la forma de sus alas, las cuales siguen la curvatura de la luna creciente, y cuyas plumas son más largas en los extremos que en el centro. Gran parecido tienen su vestimenta, el peinado y la postura de las manos que sostienen los pliegues angulosos del manto de la Virgen. Igualmente hay similitud ente los rasgos de la cara del ángel; destaca la continuidad entre el perfil de la nariz y las cejas. En ambos ejemplos, la cara de los ángeles se representa de medio perfil, sólo que el ángel de la imagen flamenca mira hacia el lado derecho a la vez que el de la mexicana, hacia el izquierdo.

Pese a las importantes semejanzas entre La Virgen en la gloria de Berlín y la imagen de la Virgen de Guadalupe, la pintura mexicana no es meramente una copia del grabado flamenco. El pintor indígena Marcos adaptó el modelo europeo a las necesidades de los frailes, de tal manera que las pinturas presentan notorias diferencias. Las más significativas son que la Virgen de 


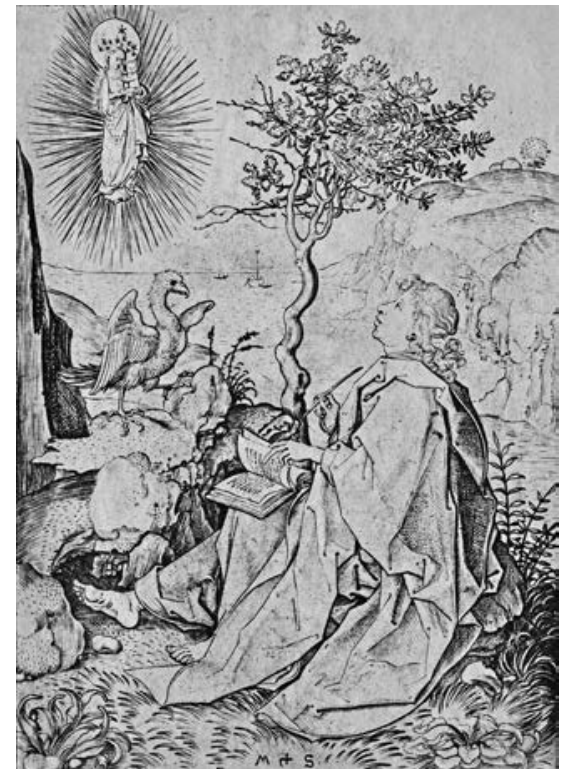

Io. Martin Schongauer, San Juan escribe el Apocalipsis en la isla de Patmos, buril sobre metal, siglo xv. Biblioteca Real de Bruselas, Gabinete de Estampas.

Guadalupe carece del Niño representado en La Virgen en la gloria, una característica de la gran mayoría de las imágenes marianas flamencas y alemanas de los siglos Xv y xvI, y que el pintor sustituyó el cabello rubio largo y flotante de la Virgen flamenca (corpus ilustrado, núms. 45-47), otro de los rasgos característicos del modelo, ${ }^{33}$ con un cabello oscuro lacio, recogido, peinado con raya en medio y adherido a ambos lados de la cabeza y cubierto por el manto. La tercera diferencia es que la Guadalupana tiene la mirada recatada y se encuentra en actitud orante, mientras que el modelo de La Virgen en la gloria de Berlín sostiene una manzana en la mano izquierda y mira al espectador. ${ }^{34}$

33. Véase, por ejemplo, la cabellera de la Virgen en el retablo políptico Adoración del cordero mistico, realizado por Jan y Hubert van Eyck en I432, para la iglesia de San Juan de Gante.

34. Otras diferencias menores entre las dos imágenes radican en que la corona de La Virgen en la gloria de Berlín es muy elaborada y está cubierta de estrellas, mientras la de la mexicana (que como quedó dicho sólo se puede apreciar en copias antiguas) únicamente consta de un aro y de elementos puntiagudos (fig. I5); que el manto y la túnica de la primera son lisos, mientras el manto de la de Guadalupe está tachonado de estrellas y la túnica, decorada con un motivo floral aplicado con patrón, ya que no respeta los pliegues de la tela; que los ángeles voltean la cabeza para el lado contrario y que los rayos de luz de la mandorla son mucho más 
II. Alberto Durero, La Virgen con el Niño, grabado, 1508 . Staatliche Museen, Berlín, Gabinete de Estampas.

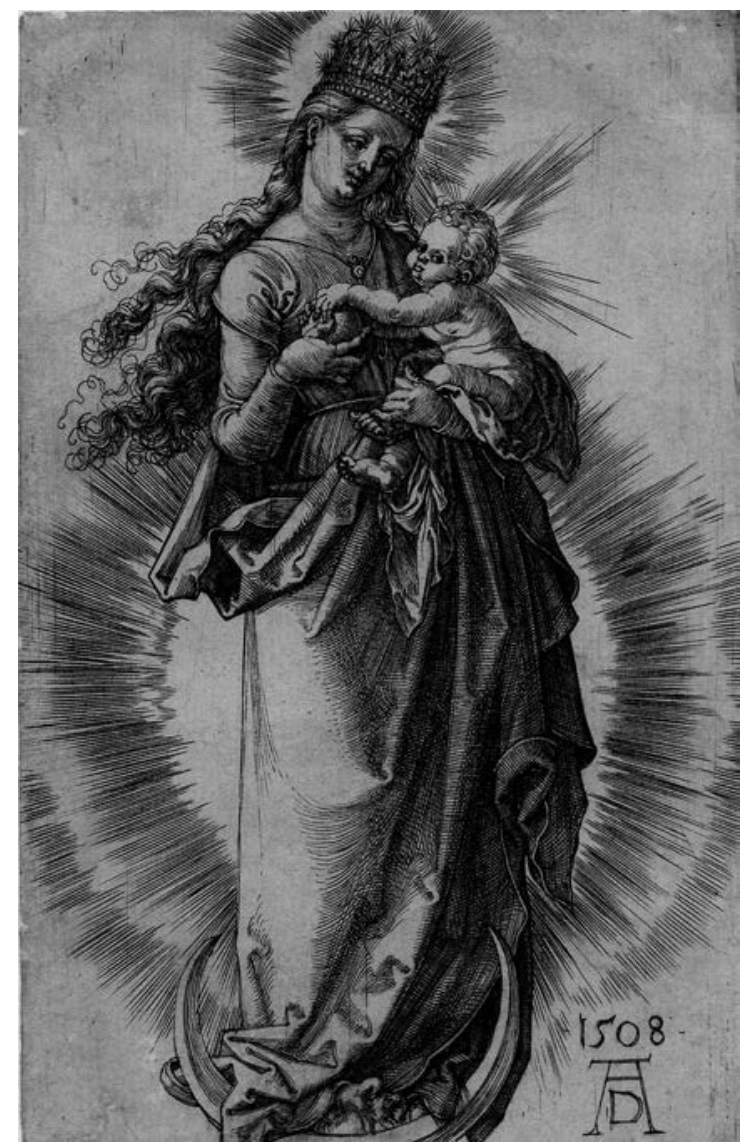

Estas diferencias, a las que me referiré con más detalle, no invalidan la hipótesis de que La Virgen en la gloria, o alguna imagen similar, haya sido la fuente utilizada por el pintor Marcos para realizar la obra, ya que era habitual que

gruesos en la obra flamenca que en la mexicana, y que en este último caso alternan uno recto y uno curvilíneo, mientras en el de la Virgen flamenca todos son curvilíneos y la alternancia es entre uno liso y uno rayado. El grabado flamenco tiene una serie de motivos fuera de la mandorla: ángeles, aves y filacterias con inscripciones en letra gótica, en idioma flamenco, que no aparecen en la pintura mexicana. 


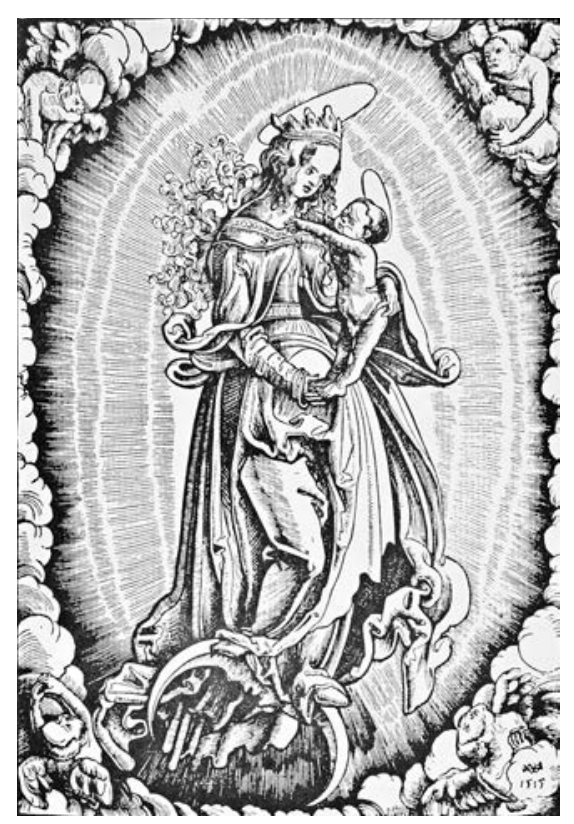

I2. Maestro de Mühldorf (atribuida), firmada IW, La Virgen con el Niño, grabado, I515. Tomada de Geisberg, The German Single-Leaf Woodcut: I500-I550 (vid supra n. 2I).

los pintores adaptaran los modelos a sus necesidades, mediante la supresión, el añadido o la alteración de ciertos elementos.

\section{La penetración de grabados flamencos en la Nueva España y su influencia en el arte del siglo XVI}

Puede explicarse cómo es que un modelo iconográfico surgido en Europa del norte durante el medievo haya sido utilizado para una pintura realizada un siglo después por un indio, en la Nueva España. En primer término, hay que aludir al gran comercio de imágenes y objetos religiosos procedentes del norte de Europa que existió en la época que nos ocupa en todo el orbe cristiano. En particular, la exportación de grabados fue muy intensa a partir del descubrimiento de la xilografía en Flandes, a principios del siglo XIv. Esta técnica permitió la impresión masiva de estampas y de pequeños libros devocionales - a partir de un pedazo de madera, de algunos instrumentos para trabajarla y de tinta y papel de impresión—, que desde el siglo XV se vendían 
I3. Anton Woensam (atribuido), La Virgen con el Niño, xilografía impresa en el libro Contra alchonarum (Colonia: Apud Petrum

Quental, I533). Tomada de Grabados alemanes de la Biblioteca Nacional (siglos XV$X V I$ ), vol. I (vid supra n. 20), 5II.

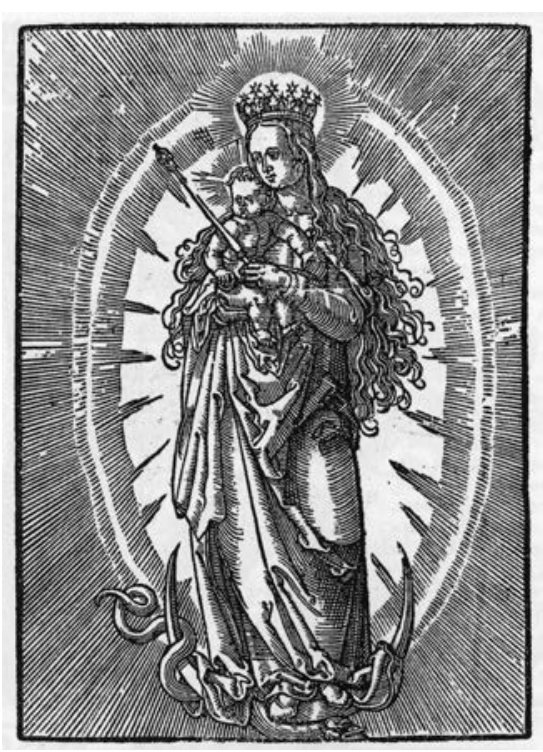

por millares durante las peregrinaciones, en las puertas de las iglesias y en las ferias. Por este medio, imágenes como las de la Virgen de Bruselas (I423), de san Sebastián de Viena (I437), de san Roque o de santa Apolonia se propagaron por todas partes, como objetos de devoción personal, patentes de cofradías e indulgencias, entre otros. A partir de la segunda mitad del siglo xv, con la invención de la imprenta en Maguncia, por Juan Gutenberg, se desarrolló un intensivo mercado de libros religiosos, muchos de los cuales estaban ilustrados con xilografías. 35

Entre los siglos XIV y XVi España se abasteció de libros, grabados y estampas de Alemania, Italia y Flandes mediante la importación; al incorporarse esta última al imperio español, en I5I9, se intensificó el comercio de objetos religiosos y artísticos de esta región. ${ }^{36}$ La presencia en España del modelo iconográfico que nos ocupa se constata mediante numerosas pinturas, esculturas, relieves, dibujos y grabados, tanto importados como realizados en Espańa. La

35. Lucien Febvre y Henri-Jean Martin, La aparición del libro, trad. Agustín Millares Carlo (México: Fondo de Cultura Económica/Fondo Nacional para la Cultura y las Artes, I999), 24-25.

36. Ralph Dekoninck, Ad imaginem: status, fonctions et usages de l'image dans la littérature spirituelle jésuite du XVII e siècle (Ginebra: Librairie Droz, 2005). 


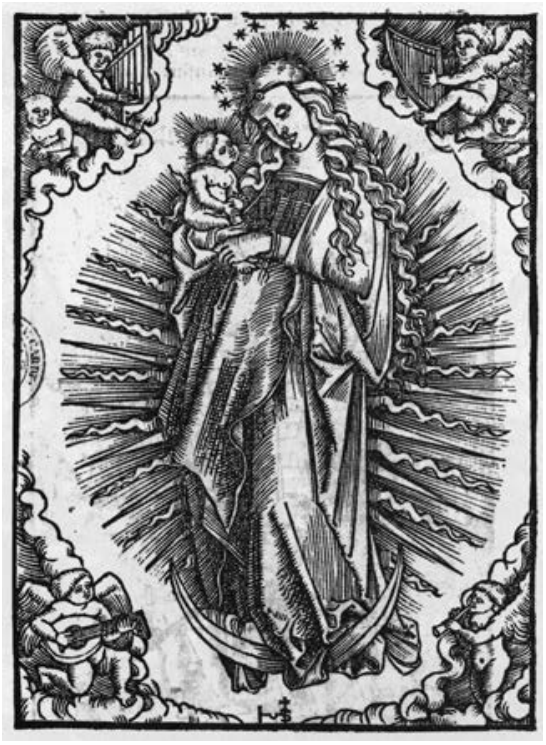

14. Heinrich Steiner, La Virgen con el Niño, rodeada de ángeles músicos, xilografía, primera mitad del siglo xvi. Tomada de Grabados alemanes de la Biblioteca Nacional (siglos XV-XVI), vol. I (vid supra n. 20), 489.

talla antes aludida de la Virgen con el Niño del coro del santuario de Guadalupe en Extremadura (fig. I7), y la reproducción del grabado de la Virgen en la gloria de Berlín (fig. 3), posible antecedente de la pintura de la Virgen de Guadalupe, con textos traducidos al castellano, son ejemplos de ello. ${ }^{37}$

Con la colonización de América muchos de estos objetos, especialmente grabados en estampas y libros, arribaron al nuevo continente, por medio de España. Otra vía mediante la cual pudieron haber llegado grabados flamencos a la Nueva España, durante la primera etapa de evangelización, fue la de los mismos misioneros. El primer contingente de franciscanos que arribó en 1523 provenía del convento de Gante, en Flandes; conformado por Johann Dekkers, Johann van den Auwera y Pieter van der Moere, conocido como Pedro de Mura o Pedro de Gante, tuvo la encomienda del emperador Carlos V, también flamenco, de cristianizar a los indios recién conquistados. Los frailes debieron haberse provisto de materiales de apoyo para emprender su delicada y difícil tarea y no resulta remoto pensar que hayan llevado consigo libros devocionales y estampas de su tierra natal. ${ }^{38}$ De los tres franciscanos flamencos, Dekkers

37. Imagen reproducida por Favrot Peterson, Visualizing Guadalupe, I2I.

38. Para diversos ejemplos sobre el tema véase: Elena Isabel Estrada de Gerlero, Muros, sargas 


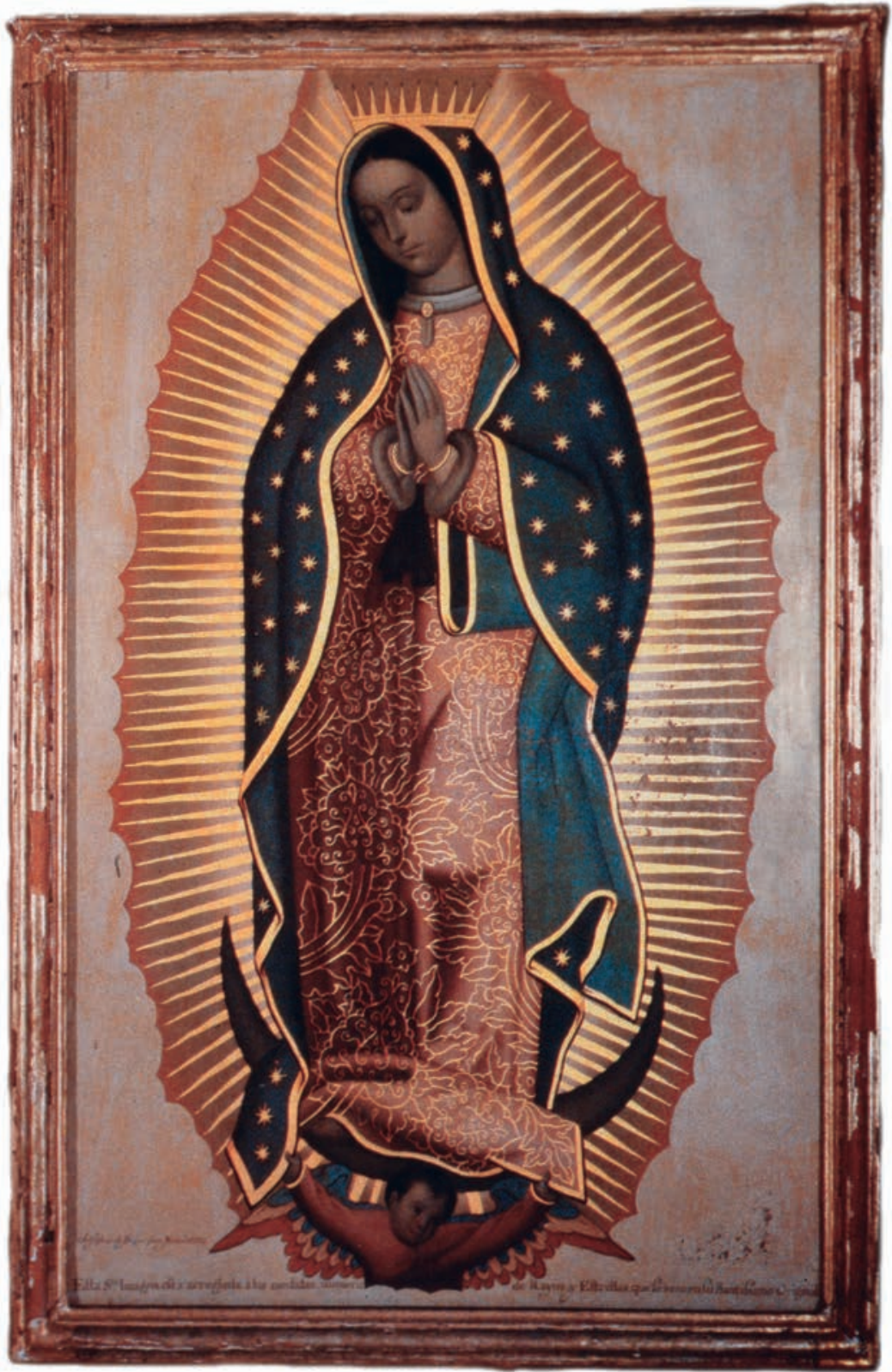

I5. José de Alcíbar, copia fiel de la Virgen de Guadalupe, óleo sobre tela, segunda mitad del siglo xvirI. Museo de Guadalupe, Zacatecas. Foto: Archivo Fotográfico Manuel Toussaint, IIE-UnAm. Conaculta-INAH-MÉx. "Reproducción autorizada por el Instituto Nacional de Antropología e Historia”. 


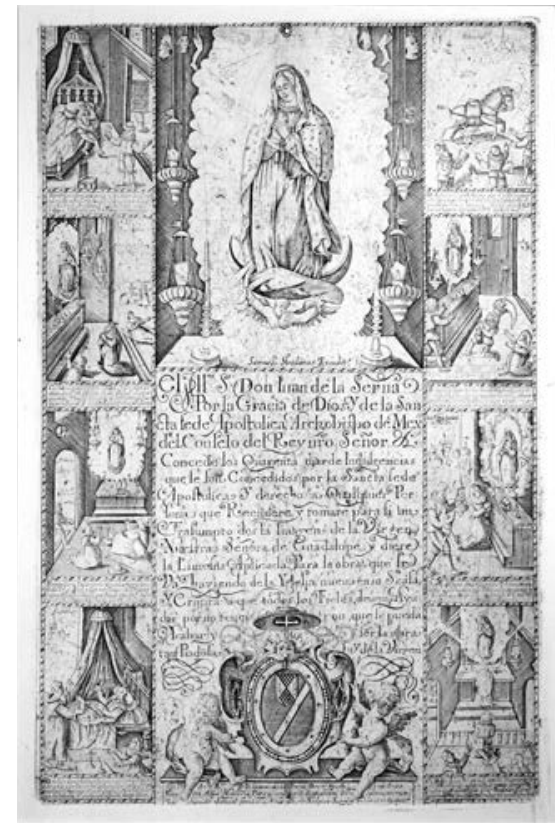

16. Samuel Stradanus, Los milagros de la Virgen de Guadalupe, calcografía, ca. 1622. Colección Museo Franz Mayer.

y Van den Auwera murieron al poco tiempo de haber llegado, pero Pedro de Gante ejerció su magisterio durante 50 años, hasta su muerte en 1572.

Es conocido que, durante la fase inicial de evangelización, las imágenes se utilizaron profusamente para despertar devoción a las nuevas figuras cristianas, como material didáctico y para transmitir por medio de ellas los principales conceptos religiosos a los indios. ${ }^{39}$ Una prueba de que Gante estuvo familiarizado con imágenes marianas del modelo que nos ocupa es la imagen de la Virgen que aparece en su Doctrina mexicana en lengua indígena, impresa en México, en 1553, por Juan Pablos.

Puesto que la pintura de la Virgen de Guadalupe se realizó en las primeras tres décadas del siglo XVI, es casi seguro que el pintor Marcos estuviera vinculado a la escuela de artes y oficios que Pedro de Gante había fundado junto

y papeles. Imagen de lo sagrado y lo profano en el arte novohispano del siglo XVI (México: Universidad Nacional Autónoma de México-Instituto de Investigaciones Estéticas, 20II); Alexander Gauvin Bailey, Art on the Jesuit Missions in Asia and Latin America, I542-I773 (Toronto y Buffalo: University of Toronto Press, 1999).

39. Véanse las imágenes alusivas a este hecho en Diego Valadés, Retórica cristiana (México: Fondo de Cultura Económica, 1989). 
17. Guillermín de Gante, La Virgen con el Niño, Coro del Santuario de Guadalupe, Extremadura, talla de madera policromada, restaurada en el xviII, siglo xv. Foto de la portada de Proceso (vid supra, n. I4).

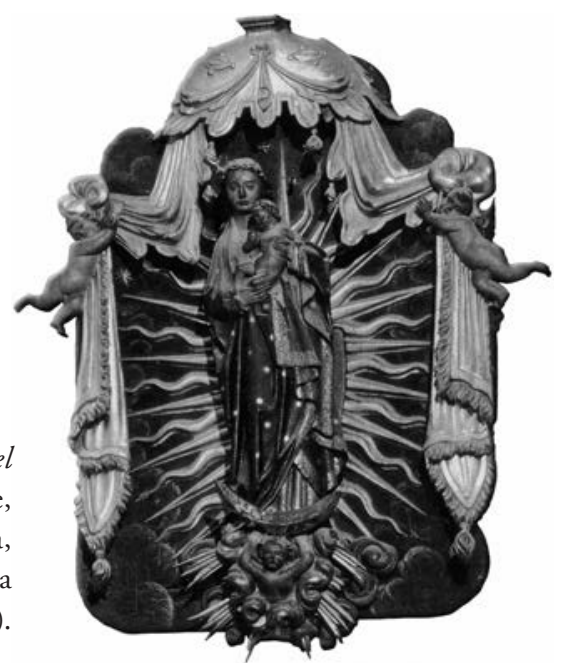

a la capilla de San José de los Naturales, dentro del perímetro del convento de San Francisco de la ciudad de México. ${ }^{40}$ En este contexto se formaron las primeras generaciones de pintores indígenas y se produjeron las imágenes religiosas y objetos de culto para las recién fundadas iglesias, santuarios, ermitas, parroquias y catedrales del virreinato. ${ }^{4 \mathrm{I}}$ En un carta de fray Pedro, de I529, dirigida a sus correligionarios de Gante, se jactó de que cada "provincia, pueblo y parroquia tuviera una iglesia o capilla con imágenes de pincel, cruces y estandartes". ${ }^{42}$

No resulta remoto pensar que el propio Gante haya proporcionado al pintor indígena la estampa o estampas que sirvieron de modelo para la realización de la obra. La copia de obras europeas era una práctica común en la época y particu-

40. Pedro Oroz, Gerónimo de Mendieta y Francisco Suárez, "Relación de la descripción de la provincia franciscana del Santo Evangelio de México", en Anales de la provincia franciscana del Santo Evangelio de México, ed. Fidel de J. Chauvet (México: Imprenta Mexicana de Juan Aguilar Reyes, 1947), 57.

41. Gerónimo de Mendieta, "Biografía de Gante", en Fray Pedro de Gante. Maestro y civilizador de América y la doctrina cristiana en lengua mexicana de 1553, ed. Ernesto de la Torre Villar (México: Seminario de Cultura Mexicana, 20or), 242.

42. Pedro de Gante, "Carta a los padres y hermanos de la provincia de Flandes del 27 de junio de 1529", en Fray Pedro de Gante, 197-200. Asimismo véase Bargellini, The Colors of the Virgin, 6. 
larmente en la escuela de artes y oficios de San José de los Naturales era necesaria puesto que los alumnos indígenas desconocían tanto el terreno artístico de las formas de la iconografía cristiana como las concepciones europeas sobre las que estaba fundada. ${ }^{43}$ Los originales en su mayoría eran estampas sueltas o grabados impresos en la Biblia y en libros devocionales, muchas de las cuales provenían de Alemania o Flandes. ${ }^{44}$ El cronista franciscano Gerónimo de Mendieta se refiere a la influencia nórdica en las obras realizadas por los indios en el siglo Xvi: "Mas después que [los indios] fueron cristianos y vieron nuestras imágenes de Flandes y de Italia, no hay retablos ni imagen, por prima que sea, que no la retraten y contrahagan". 45

La influencia de los grabados europeos, y en especial los flamencos, ha sido ampliamente documentada. ${ }^{46}$ Ejemplos de la utilización del estereotipo de la mulier amicta sole en el siglo Xvi, además del de la imagen de la Virgen de Guadalupe, son, entre otros, una obra plumaria con la Virgen como Tota pulchra, perteneciente al Museo de América de Madrid (fig. I8), que tiene gran similitud con un pequeño grabado anónimo del siglo XV o principios del Xvi, perteneciente al Museo Británico de Londres (corpus ilustrado, núm. 37); y la representación de la Virgen como Tota pulchra de la portería del convento de los Santos Reyes de Metztitlán, fechada hacia 1577, que está basada en el grabado de la Virgen sobre la luna creciente acompañada de los signos de la letanía, diseñado por Philipp Galle y grabado por Hieronymus Wierix, aunque tiene algunos cambios en los atributos. ${ }^{47}$ Otros ejemplos son la pin-

43. Para mayor información acerca de las primeras escuelas franciscanas en territorio americano véase: Francisco Borgia Steck, El primer colegio de América Santa Cruz de Tlatelolco (México: Centro de Estudios Franciscanos, 1944) y Robert Ricard, La conquista espiritual de México (México: Fondo de Cultura Económica, I986).

44. A la fecha se han logrado identificar, para México y Perú, numerosos grabados utilizados como fuente de pinturas de códices, murales y obras de caballete. Un acervo nutrido es el Project of the Engraved Sources of Spanish Colonial Art (PESSCA), http://colonialart.org/archive/the-virgin-mary/the-conception-of-the-virgin/the-virgin-as-tota-pulchra\#cI2IIa-I2Irb, consultado el I2 de junio de 2014.

45. Gerónimo de Mendieta, Historia eclesiástica indiana (México: Antigua Librería Portal de Agustinos, I770), 404.

46. Especialmente artistas como Alberto Durero, Martin Schongauer y Peter Paul Rubens las reprodujeron mucho. Pablo Escalante Gonzalbo, "La influencia del grabado flamenco en la Nueva España”, en Libros y grabados flamencos en el imperio hispano-portugués (siglos XVIXVIII), eds. Walter Thomas y Eddy Stols (Lovaina/La Haya: Acco Lovaina 2009), I99-2I5.

47. Esta obra ha sido estudiada por Escalante Gonzalbo, "La influencia del grabado flamenco", 208. La estampa flamenca forma parte de la colección del Museo Plantin-Moretus 


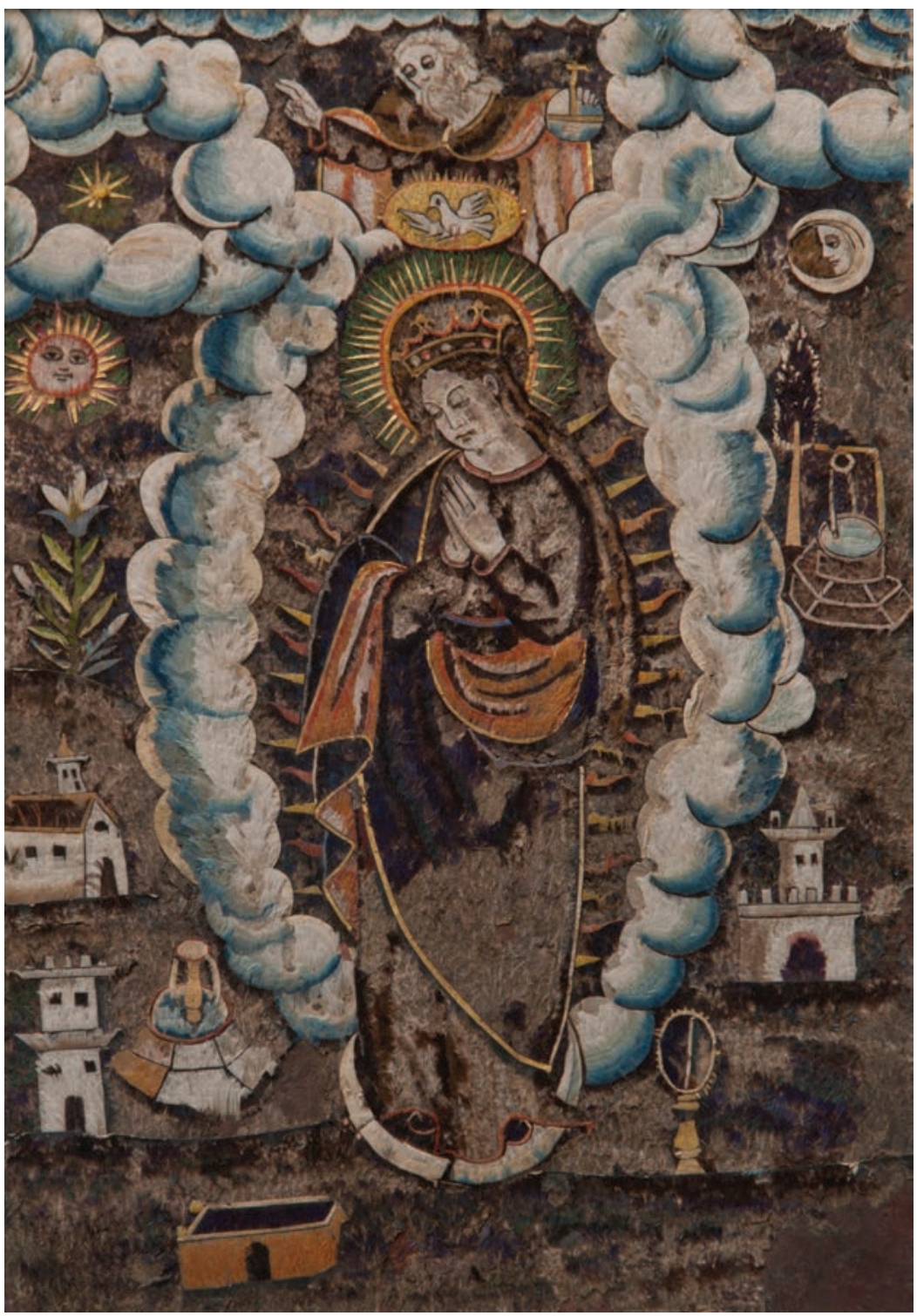

$\oplus$

18. Anónimo, Tota pulchra, arte plumario, siglo xvi. Museo de América, Madrid, núm. de inventario I233I. 
tura de la Virgen como Tota pulchra de la portería del convento franciscano de Huejotzingo, y un grabado de la Virgen del Rosario, de Juan Ortiz, realizado en I57I (fig. 19), cuya fuente parece ser el anónimo alemán La Virgen con el Niño en gloria sobre luna creciente y los cuatro evangelistas (corpus ilustrado, fig. 52) o una obra similar (corpus ilustrado, fig. 50) que comparte las mismas características.

A partir de las fuentes europeas los artistas indígenas de la Nueva España crearon nuevas composiciones, que respondieron a las necesidades de los emisores y receptores de las obras.

\section{La creación de una nueva imagen mariana por parte del indio Marcos}

La imagen de la Virgen de Guadalupe surgió en el contexto de la primera etapa de evangelización. Juan de Torquemada informa en su Monarquía indiana que pocos años después de la Conquista — probablemente en I53I, el año consignado en el mito-, el santuario prehispánico del Tepeyac, situado en el cerro del mismo nombre, fue transformado por frailes franciscanos en una ermita cristiana dedicada a "nuestra señora y madre" la Virgen María. ${ }^{8}$ En tiempos prehispánicos el cerro del Tepeyac había sido un lugar sagrado dedicado a la diosa madre Tonantzin-Cihuacóatl, "la madre o nodriza de la humanidad, la progenitora Virgen, la patrona de los nacimientos y de las mujeres muertas en el parto” (fig. 20). Era la deidad femenina más importante del panteón mexica, a quien se le rendía culto mediante cantos y danzas y que era visitada por peregrinos que llegaban desde lejos. ${ }^{49}$ La pintura de la Guadalupana se realizó con

de Amberes. Para tener una visión general de la obra de Wierix véase: Les estampes des Wierix conservées au Cabinet des estampes de la Bibliothèque Royale Albert Ier: catalogue raisonné, enrichi de notes prises dans diverses autres collections, ed. Marie Mauquoy-Hendrickx; introd. Louis Lebeer, 3 vols. (Bruselas: Bibliothèque Royale Albert Ier, 1978-I983). Para estudiar casos específicos como el de la casa editorial de Christopher Plantin véase: M. Rooses, Christoph Plantin, imprimeur anversois (Amberes: Buschmann, I883) y Leon Voet, The Golden Compasses, 2 vols. (Ámsterdam: Vangendt, 1969); para el caso americano véase Linda Báez Rubí, Mnemosine novohispánica: retórica e imágenes en el siglo XVI (México: Universidad Nacional Autónoma de México-Instituto de Investigaciones Estéticas, 2005), 215-288.

48. Juan de Torquemada, Monarquía indiana (México: Salvador Chávez Hayhoe, I943), libro Io, cap. 7, 246.

49. Bernardino de Sahagún, "Adición sobre supersticiones", en Historia general de las cosas de Nueva España, ed. Ángel María Garibay (México: Porrúa, I969), cap. II, apéndice, 352. 


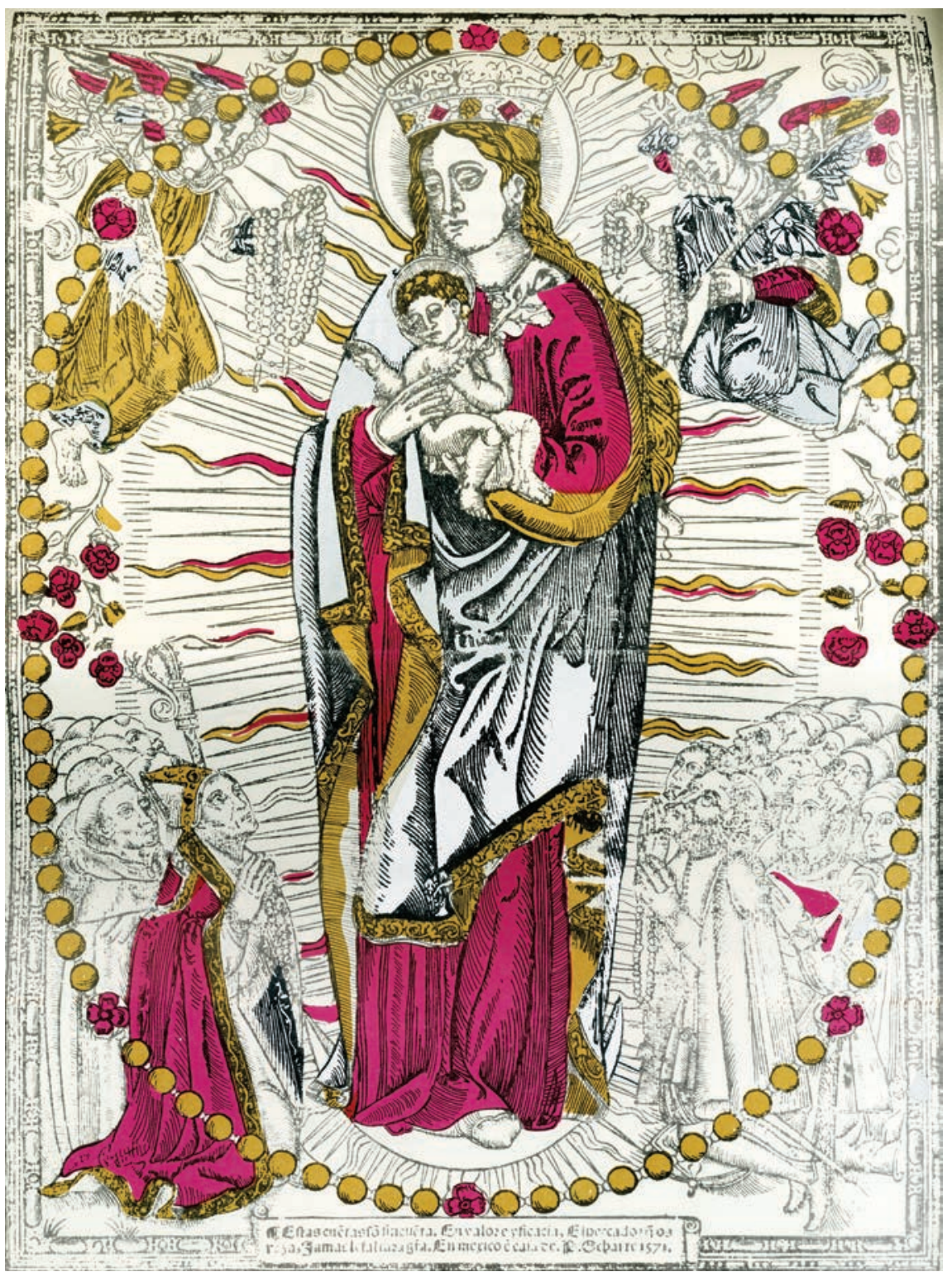

$\oplus$

19. Juan Ortiz, La Virgen del Rosario, I57I, xilografía coloreada, realizado en el taller de Pedro Ocharte. Biblioteca Nacional de México. Tomado de Alexander A.M. Stols, Pedro Ocharte, el tercer impresor mexicano (México: Universidad Nacional Autónoma de México, 1990), lám. I6. 
el propósito de sustituir las imágenes del santuario de Cihuacóatl, para reorientar el culto que se le tributaba hacia la Virgen María. Transformar lugares de culto paganos en recintos cristianos era una práctica común que databa desde los inicios del cristianismo..$^{\circ}$ Otras devociones de sustitución que llegaron a ser muy exitosas fueron las de las Vírgenes de Izamal, en Yucatán; de Zapopan, en las inmediaciones de Guadalajara, y de la Salud, en Pátzcuaro; así como del Santo Señor de Chalma, en Ocuilan, hoy Estado de México.

La pintura de la Virgen de Guadalupe se realizó entre 1523, año en que llegaron los primeros franciscanos, y I556, momento en que ya estaba bien establecido el culto y a la imagen se le atribuían varios milagros, según se infiere de la mencionada confrontación entre el arzobispo Montúfar y el prior Bustamante. Durante este lapso la realización de pinturas y demás artículos religiosos estuvo casi exclusivamente en manos de los indios bajo la tutela de los frailes, ya que todavía no se habían establecido artistas europeos en la Nueva España. ${ }^{51}$

Puesto que la pintura de la Virgen de Guadalupe fue un encargo de los franciscanos y, si consideramos su temprana realización, quizá se llevó a cabo en el contexto de la escuela de artes y oficios, el lugar donde se hacían en esa época todos los objetos religiosos con los que se dotaron los distintos recintos de culto que se construyeron en esa época.

Respecto a la autoría de la imagen de la Guadalupana, merece crédito la afirmación del provincial franciscano Bustamante de que fue obra del indígena Marcos, porque él debió estar bien informado sobre este hecho, sucedido a lo mucho 25 años atrás. Además su declaración se reafirma por no haber sido objetada por ninguno de los testigos, a pesar del enojo e indignación que había despertado entre ellos. ${ }^{2}$ Pero, ya que sólo mencionó el nombre de pila del pintor, no se le puede identificar con certeza. Algunos estudiosos han planteado la posibilidad de que se trate del afamado pintor indio Marcos Cipac de Aquino, ${ }^{53}$ apodado Apeles o Griego, que gozó de gran prestigio en su época y

50. Jean Seznec, Los dioses de la Antigüedad (Madrid: Taurus, 1983).

5I. El sevillano Andrés de Concha llegó a la Nueva Espańa en i560, el flamenco Simón Pereyns lo hizo en 1566 y el vasco Baltasar de Echave Orio, en I573. De este último, la primera copia que se le conoce de la imagen de la Virgen de Guadalupe data de 1606. Vargaslugo, "Apuntes sobre la pintura guadalupana", 189.

52. "Era una pintura que había hecho Marcos, indio pintor", testimonio de Alonso Sánchez de Cisneros, "Denuncias sobre la casa de nuestra Señora de Guadalupe", 63.

53. Toussaint, Pintura colonial en México, 24. 
20. La diosa Tonantzin como Cihuacóatl, escultura náhuatl, ca. I500. Museo Nacional de Antropología e Historia, México. Conaculta-INAH-méx. "Reproducción autorizada por el Instituto Nacional de Antropología e Historia”.

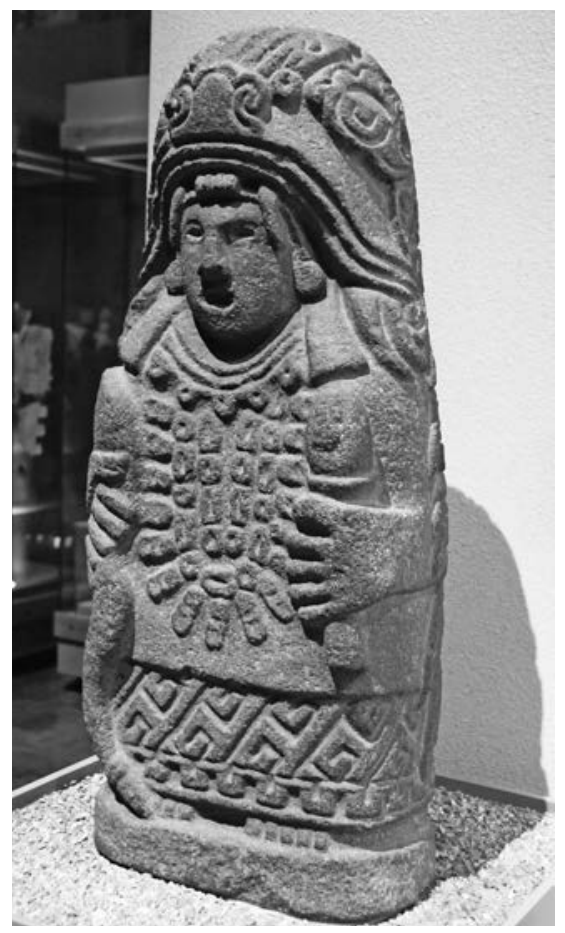

cuyo oficio le pareció a Bernal Díaz del Castillo tan notable como los de Apeles, Berruguete y Miguel Ángel.54 Esta hipótesis parece viable por la calidad de la pintura, porque Marcos Cipac vivió entre I5I7 y I572, y, por tanto, pudo haber realizado la pintura de joven, y porque sabemos que posteriormente participó en la realización del altar principal de la capilla de San José de los Naturales del convento de San Francisco de México, lo cual indica que era cercano a los franciscanos y que valoraban su trabajo. .5

El pintor Marcos adaptó el grabado europeo para cumplir la función asignada por los religiosos cuyo objetivo era suplantar la imagen de Tonatzin-

54. Bernal Díaz del Castillo, Historia verdadera de la conquista de la Nueva España, ed. Joaquín Ramírez Cabañas, Sepan Cuántos 5 (México: Porrúa, 1970), cap. 9I.

55. Pedro Ángeles Jiménez, Apeles y tlacuilos: Marcos Griego y la pintura cristiano indígena del siglo XVI en Nueva España, 95-96, http://dspace.unav.es/dspace/bitstream/Ior71/18082/I/IO_Jimenez.pdf, consultado el is de mayo de 2014. 
Cihuacóatl, y de tal manera canalizar la devoción hacia la Virgen y contribuir a la evangelización de los indígenas del altiplano central.

Entre las modificaciones destaca el hecho de que la imagen carezca del Niño, mismo que distingue a la mayoría de las imágenes marianas del siglo $\mathrm{XV}$ y primeras décadas del XVI y, con pocas excepciones, es una de las características de la mulier amicta sole. Al parecer esto obedeció al interés de los franciscanos de promover la idea de la Inmaculada Concepción de María, o sea de su gestación libre del pecado original.56 La orden de San Francisco fue una de las primeras instituciones eclesiásticas que aceptó esta creencia. En I263 la integró a sus ordenanzas y se comprometió a difundirla entre los fieles, lo cual implicó defenderla frente a los sectores de la Iglesia que se oponían a ella, como los dominicos, que objetaban su validez por no encontrar fundamentos bíblicos que la sustentaran. Los franciscanos evangelizadores de las primeras generaciones, fieles a los preceptos de su orden, propagaron esta creencia en la Inmaculada Concepción de María entre los indígenas recién convertidos, por medio de la predicación, la doctrina y las imágenes. Como era una creencia vanguardista y controvertida y todavía no había una forma específica para representarla plásticamente, los franciscanos recurrieron a una mulier amicta sole. ${ }^{77}$ En la mayoría de los santuarios fundados por ellos introdujeron imágenes de la Virgen sin Niño, como sucedió en Zapopan e Izamal.

Otra razón por la cual la imagen guadalupana aparece sin Niño pudo deberse a que eligieran una figura cristiana con características similares a las de Tonantzin-Cihuacóatl, a la cual pretendían suplantar. Con el fin de facilitar la sustitución de las imágenes paganas por cristianas los frailes solían escoger figuras cristianas con características parecidas. Por ejemplo, en Chiauhtempan, la diosa abuela Toci fue sustituida por santa Ana, la abuela de Jesucristo; en Tianquizmanalco, Telpuchtli, el dios mancebo, fue suplantado por san Juan Bautista, y la diosa Tonan, por la Virgen María. ${ }^{58}$

56. La doctrina de la Inmaculada Concepción de María fue una de las más controvertidas de la Iglesia católica desde el siglo xiI, cuando llegó a la Península Ibérica, procedente de Oriente, hasta el siglo XIx, cuando se aceptó como dogma. La plena aceptación de la creencia inmaculista no se logró hasta el siglo xix, con la bula Ineffabilis Deus de i854, que convirtió esta creencia en un dogma de fe. Cuadriello, "Virgo Potens", II88-II92 y José Cristo Rey García Paredes, Mariología (Madrid: Biblioteca de Autores Cristianos, 2005), 254-255.

57. En el siglo xvi, la Inmaculada Concepción de María se representaba asimismo como Tota pulchra o como Virgen de la Ascención. Favrot Peterson, Visualizing Guadalupe, I22-I29.

58. Sahagún, "Adición sobre supersticiones", 354. 
Como señalé, otro cambio notorio se llevó a cabo en el cabello. La cabellera característica de las representaciones flamencas de la mulier amicta sole fue sustituida por un cabello oscuro, oculto bajo el manto que se proyecta hasta la cabeza y la cubre. El peinado sobrio es similar al que usaban las mujeres indígenas nobles casadas - las solteras usaban el cabello suelto- en el siglo XVI. ${ }^{59}$ Este peinado se advierte, por ejemplo, en las representaciones de la Malinche en el Lienzo de Tlaxcala. ${ }^{60}$ Una cabellera ondulada y flotante probablemente les hubiera resultado ajena, mientras que el peinado de la Guadalupana les era familiar e inspiraba respeto, al ser propio de un rango de mujeres indígenas.

La imagen de la Guadalupana denota un mayor recogimiento que las flamencas. Mientras muchas de estas últimas refuerzan la condición material de María y muestran una relación natural con el hijo, la primera aparece con la mirada baja, en actitud orante. La oración y el recato eran prácticas que los frailes trataban de inculcar a los indios y mediante las cuales les prometían llegar al cielo y evadir el infierno. ${ }^{61}$

Finalmente Marcos, al dotar a la nueva imagen de la Virgen con cabello y ojos oscuros la hizo parecida al tipo físico de los indios y de muchos de los pobladores de la Nueva Espańa. Esto permitió que los novohispanos se identificaran con ella; no en balde se le empezó a conocer como la Virgen morena.

Mediante estos cambios, surgió una nueva imagen mariana, única de su género. En la medida en que esta nueva creación se fue sacralizando y aumentó el número de sus devotos, dio origen a una nueva advocación mariana: la Virgen de Guadalupe mexicana. ${ }^{62}$ Esta nueva representación de María resultó más

59. En el dictamen de 1756, el pintor Miguel Cabrera afirma que le había dicho que el peinado que lleva la Guadalupana era similar al que usaban las mujeres indígenas de clase alta. Véase Maravilla americana y conjunto de raras maravillas observadas en la dirección de las reglas del arte de la pintura en la prodigiosa imagen de Nuestra Señora de Guadalupe de México (México: Jus, za ed. facsimilar, 1977), 23.

6o. Véanse las representaciones de mujeres indias donadoras de obras religiosas en Imágenes de los naturales en el arte de Nueva España, siglos VI al XVIII, coord. Elisa Vargaslugo (México: Fomento Cultural Banamex /Universidad Nacional Autónoma de México, 2005), 25I, 254, 262 y 285 .

6I. Gisela von Wobeser, "Los 'caminos del bien y del mal' en la pintura novohispana", Arte de América Latina. Estudios del arte precolombino e iberoamericano (Varsovia: Instituto Polaco de Investigación del Arte Mundial, en proceso de edición).

62. David A. Brading, La Virgen de Guadalupe. Imagen y tradición, trad. de Aura Levy y Aurelio Major (México: Taurus, 2002), 193-266; David A. Brading, Mexican Phoenix: Our Lady of Guadalupe: Image and Tradition Across Five Centuries (Cambridge University Press, 200I). 
vigorosa y más convincente que las imágenes de culto importadas de Europa y con el paso del tiempo logró imponerse a ellas. Su importancia fue tal que en la segunda mitad del siglo XVI o a principios del siglo XVII surgió la leyenda de las apariciones de la Virgen y de su impresión milagrosa en el ayate de Juan Diego, mediante la cual su factura fue adjudicada a una mano celestial. ${ }^{63}$

En su singularidad radicó gran parte de su fuerza, así como su capacidad de convertirse, primero, en patrona de México y, posteriormente, de América.

Dado que el estudio de una imagen como la Guadalupana es una tarea muy difícil, de la cual quedan pendientes muchos aspectos, incluyo un corpus ilustrado de imágenes del ámbito flamenco-alemán del siglo xv y las tres primeras décadas del siglo XVI, perteneciente al modelo de la mulier amicta sole, con la finalidad de que constituya un antecedente para futuras investigaciones. \$s

63. Entre los autores que ubican el surgimiento de la leyenda en la segunda mitad del siglo Xvi están: Miguel León-Portilla, Tonantzin Guadalupe. Pensamiento náhuatl y mensaje cristiano en el "Nican mopohua" (México: El Colegio Nacional/Fondo de Cultura Económica, 2000); Edmundo O'Gorman, Destierro de sombras. Luz en el origen de la imagen y culto de Nuestra Señora de Guadalupe del Tepeyac (México: Universidad Nacional Autónoma de México, 1986). Entre los autores que sitúan la leyenda en el siglo Xvir están James Lockhart, The Nahuas after the Conquest: A Social and Cultural History of the Indians of Central Mexico. Sixteenth Through Eighteenth Centuries (Stanford University Press, 1992), entre otros.

N.B. Este trabajo obtuvo el respaldo de la Dirección General de Asuntos del Personal Académico, por medio de su Programa de Apoyo a Proyectos de Investigación e Innovación Tecnológica (рАРітT). Agradezco la lectura y comentarios de Antonio Rubial, Martha Fernández, Berta Gilabert, Abraham Villavicencio y Javier Dávila. 
DOI: http://dx.doi.org/10.22201/iie.18703062e.2015.107.2558

ANTECEDENTES ICONOGRÁFICOS

\section{Corpus ilustrado}

I. Anónimo, La Virgen del Rosario y el Niño, xilografía, siglo xv. Londres, British Museum. CC-BY-NCSA 4.O.

2. Anónimo, La Virgen del Rosario y el Niño, xilografía coloreada, siglo xv. Londres, British Museum. CC-BY-NCSA 4.O.

3. Anónimo, La Virgen del Rosario y el Niño, xilografía coloreada, siglo xv. Londres, British Museum. CC-BY-NCSA 4.O.

4. Anónimo, La Virgen del Rosario y el Niño con Santo Domingo, xilografía, siglo xv. Londres, Colección Fotográfica Warburg Institute.

5. Anónimo, La Virgen y el Niño en gloria, coronada por ángeles, xilografía coloreada, siglo Xv. Londres, British Museum. CC-BY-NCSA 4.O.

6. Master Es, La Virgen sobre luna creciente, sosteniendo al Niño, rodeada de un halo de flamas y coronada por ángeles, grabado en metal por Israhel van Meckenem, ca. I490-I500. Londres, British Museum. CC-BY-NCSA 4.0.

7. Anónimo, La Virgen y el Niño en gloria, coronada por ángeles, xilografía coloreada, ca. I475-I490. Viena, Graphische Sammlung Albertina, DGI930/II3.

8. Anónimo, La Virgen y el Niño en gloria, coronada por ángeles, xilografía, siglo xv. Londres, Colección Fotográfica Warburg Institute.

9. Anónimo, La Virgen y el Niño en gloria con los instrumentos de la pasión, xilografía, siglo xv. Tomada de The German Single-leaf Woodcuts before I5oo: Anonymous Artists, de The Illustrated Bartsch, vol. I64 (Nueva York: Abaris Books, 198I), I053.

Io. Anónimo, La Virgen y el Niño en gloria con los instrumentos de la pasión, xilografía, siglo xv. Ámsterdam, Rijksmuseum, RP-P-I939-I89.

II. Anónimo, La Virgen y el Niño con los símbolos de los evangelistas, grabado de portada del libro Plenarium (Augsburgo: Johann Schönsperger y Thomas Rüger, I48I). Londres, Colección Fotográfica del Warburg Institute.

I2. Anónimo, La Virgen y el Niño en gloria sobre luna creciente con los símbolos de los evangelistas, xilografía coloreada, siglo xv. Viena, Graphische Sammlung Albertina, DGI93O/II2.

13. Anónimo, La Virgen y el Niño en gloria con santa Bárbara y santa Catalina, xilografía coloreada, siglo Xv. Londres, British Museum. CC-BY-NCSA 4.O.

I4. Anónimo, La Virgen y el Niño en gloria con tres agustinos, xilografía, siglo xv. Londres, Colección Fotográfica Warburg Institute. 
15. Anónimo, La Virgen y el Niño flanqueados por un ángel y san Meinardo, xilografía, siglo Xv. Londres, British Museum. CC-BY-NCSA 4.O.

16. Alberto Durero, La Virgen coronada con cetro y Niño sobre luna creciente, rodeada por monjes cartujos, san Juan Bautista y san Bruno, xilografía, I515. Londres, British Museum. CC-BY-NCSA 4.O.

17. Anónimo, La Virgen coronada, flanqueada por santa Ana y santa Brígida, xilografía, $c a$. I470-I490. Ámsterdam, Rijksmuseum, RP-P-I888-A-I399I.

I8. Master S., La Virgen coronada, sosteniendo a Cristo niño sobre luna creciente y un halo radiante con un santo ataviado con hábito de monje a la derecha, xilografía coloreada, I500-I525. Londres, British Museum. CC-BY-NCSA 4.O.

19. Alberto Durero, La Virgen y el Niño sentados sobre luna creciente, grabado en metal, 1504. Londres, Colección Fotográfica Warburg Institute.

20. Alberto Durero, La Virgen y el Niño de pie sobre luna creciente, grabado en metal, I5I4. Londres, Colección Fotográfica Warburg Institute.

21. Alberto Durero, La Virgen y el Niño de pie sobre luna creciente, grabado en metal, I5I6. Londres, British Museum. CC-BY-NCSA 4.O.

22. Anónimo, La Virgen y el Niño en gloria sobre luna creciente, xilografía coloreada, siglo Xv. Ámsterdam, Rijksmuseum, RP-P-1922-244.

23. Anónimo, La Virgen y el Niño en gloria sobre luna creciente, xilografía coloreada, siglo xv. Londres, Colección Fotográfica Warburg Institute.

24. Hans Ladenspelder, La Virgen y el Niño en gloria; coronada y con cetro sobre luna creciente, xilografía, ca. siglo Xv. Londres, British Museum. CC-BY-NCSA 4.O.

25. Anónimo, La Virgen y el Niño en gloria sobre luna creciente, procedente de un libro de horas flamenco, xilografía coloreada, ca. I500-I525. Londres, British Museum. CC-BY-NCSA 4.O.

26. Anónimo, La Virgen y el Niño en gloria sobre luna creciente, xilografía coloreada, siglo Xv. Ámsterdam, Rijksmuseum, RP-P-I996-94.

27. Anónimo, La Virgen y el Niño en gloria sobre luna creciente, xilografía, siglo Xv. Ámsterdam, Rijksmuseum, RP-P-I89I-A-I6524.

28. Anónimo, La Virgen y el Niño en gloria sobre luna creciente, xilografía coloreada, siglo xv. Londres, Colección Fotográfica del Warburg Institute.

29. Anónimo, La Virgen y el Niño en gloria sobre luna creciente, xilografía, siglo XV. Rijksmuesum, RP-P-I888-A-I399I.

30. Johann Otmar, La Virgen y el Niño en gloria, coronada por ángeles y rodeada de los evangelistas, procedente del frontispicio del libro Pelbartus of Temesvar, 'Stellarium Corone benedicte marie virginis' (Augsburgo: Johann Otmar, I5O2). Londres, British Museum. CC-BY-NCSA 4.O. 
3I. Israhel van Meckenem, La Virgen y el Niño de pie sobre luna creciente, grabado en metal, siglo xv. Ámsterdam, Rijksmuseum, RP-P-OB-886.

32. Anónimo, La Virgen y el Niño de pie sobre luna creciente, grabado en madera, ca. siglo xv. Londres, Colección Fotográfica del Warburg Institute.

33. Maestro del Gabinete de Ámsterdam, Virgen sobre luna creciente, grabado a punta seca, $c a$. I488-I492. Ámsterdam, Rijksmuseum, RP-P-OB-885.

34. Anónimo, La Virgen y el Niño en gloria sobre luna creciente, grabado, I520. Londres, Colección Fotográfica del Warburg Institute.

35. La Virgen sobre luna creciente (con mandorla), impreso por Heinrich Aldegever, según Alberto Durero, xilografía, I527. Ámsterdam, Rijksmuseum, RP-P-OB-2668.

36. Anónimo, La Virgen y el Niño de medio cuerpo sobre luna creciente con rezo a la Inmaculada Concepción, grabado en metal, siglo xv. Londres, Colección Fotográfica del Warburg Institute.

37. Monogramista M, La Virgen con el Niño, xilografía, siglo xv. Londres, British Museum. CC-BY-NCSA 4.O.

38. Anónimo, La Virgen con el Niño, xilografía coloreada, siglo xv. Londres, British Museum. CC-BY-NCSA 4.O.

39. Anónimo, La Virgen con el Niño, xilografía coloreada, siglo xv. Ámsterdam, Rijksmuseum, RP-P-I88I-A-4686.

40. Anónimo, La Virgen con el Niño, xilografía, siglo xv. Londres, British Museum. CC-BY-NCSA 4.O.

4I. Monogramista MR, La Virgen sobre luna creciente con el Niño rodeado de luz bajo un arco, tomada de un libro de horas flamenco, xilografía, ca. siglo Xv. Londres, British Museum. CC-BY-NCSA 4.O.

42. Anónimo, La Virgen con el Niño en gloria sobre luna creciente, xilografía coloreada, siglo Xv. Ámsterdam, Rijksmuseum, RP-P-OB-1567.

43. Anónimo, La Virgen con el Niño en gloria sobre luna creciente, grabado en metal, siglo XVI. Ámsterdam, Rijksmuseum, RP-P-OB-1567.

44. Monogramista ASF, La Virgen con el Niño en gloria sobre luna creciente, grabado en metal, siglo XVI. Ámsterdam, Rijksmuseum, RP-P-OB-3II4.

45. Alberto Durero, La Virgen con el Niño sobre luna creciente, grabado en metal, ca. siglo Xv. Londres, British Museum. CC-BY-NCSA 4.o.

46. Maestro IW (atribuido a Mühldorf), La Virgen con el Niño de pie sobre luna creciente. Londres, British Museum. CC-BY-NCSA 4.O.

47. Lucas van Leyden, La Virgen con el Niño de pie sobre luna creciente, grabado en metal, I523. Ámsterdam, Rijksmuseum, RP-P-OB-I66I. 
DOI: http://dx.doi.org/10.22201/iie.18703062e.2015.107.2558

$2 \mathrm{I} 2$

GISELA VON WOBESER

48. Anónimo, La Virgen y el Niño en gloria, xilografía, siglo xv. Londres, British Museum. CC-BY-NCSA 4.O.

49. Hans Sebald Beham, La Virgen y el Niño, grabado en metal, siglo Xvi. Londres, Colección Fotográfica Warburg Institute.

50. Maestro del Gabinete de Ámsterdam, La Virgen con el Niño, grabado a punta seca, $c a$. I488-I492. Ámsterdam, Rijksmuseum, RP-P-ов-888.

5I. Anónimo, La Virgen con el Niño sobre luna creciente, xilografía coloreada, siglo xv. Viena, Graphische Sammlung Albertina, DGi930/III.

52. Anónimo, La Virgen con el Niño en gloria sobre luna creciente y los cuatro evangelistas, xilografía coloreada, siglo xv. Tubinga, Universitätsbibliothek. 


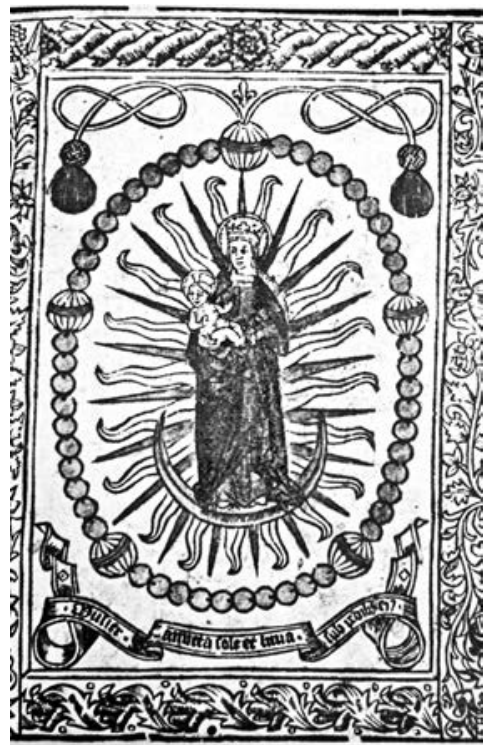

I

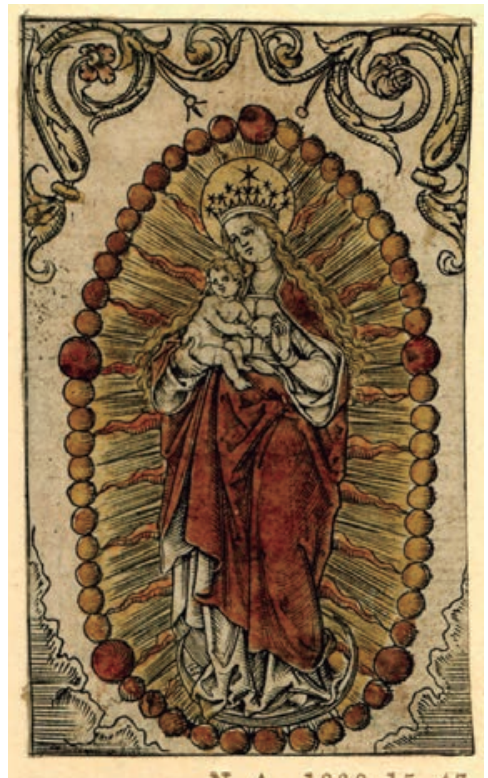

N. A.. 1868.15 .47

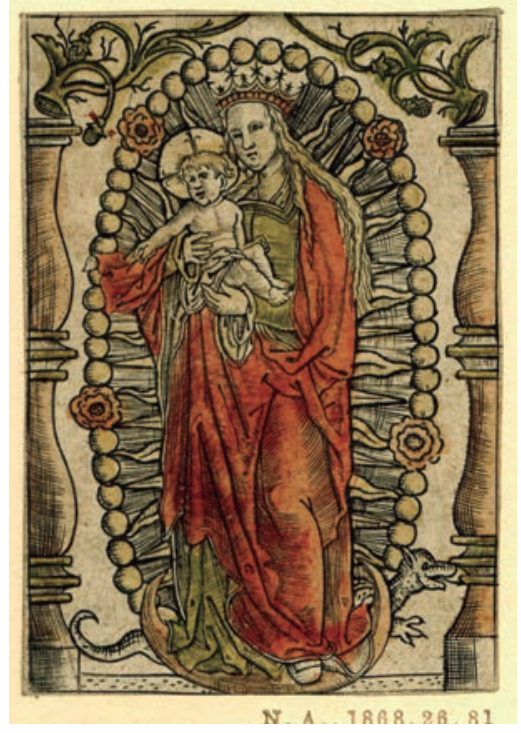

2

$\oplus$

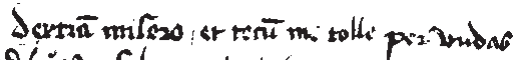

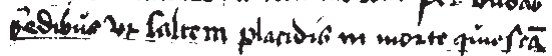

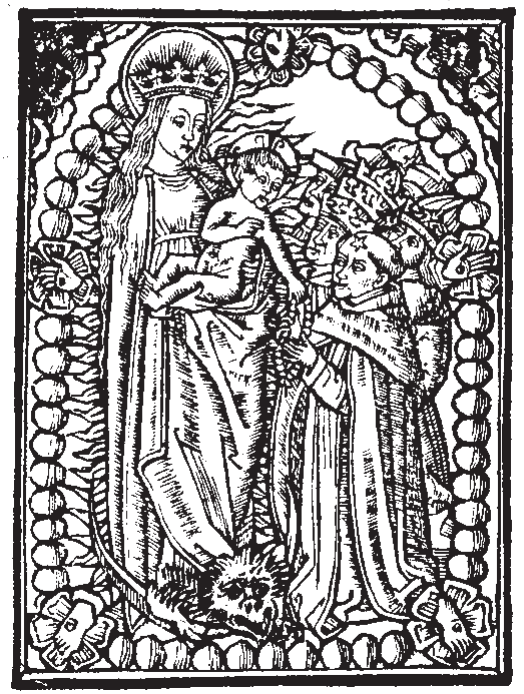

4 
DOI: http://dx.doi.org/10.22201/iie.18703062e.2015.107.2558

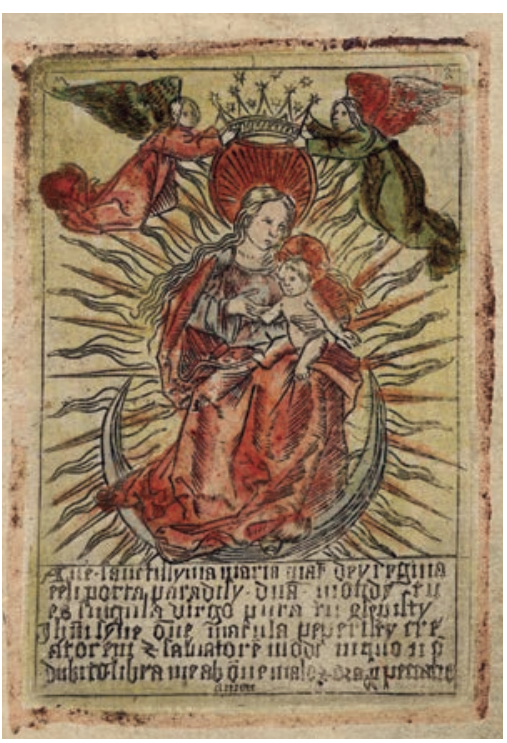

5

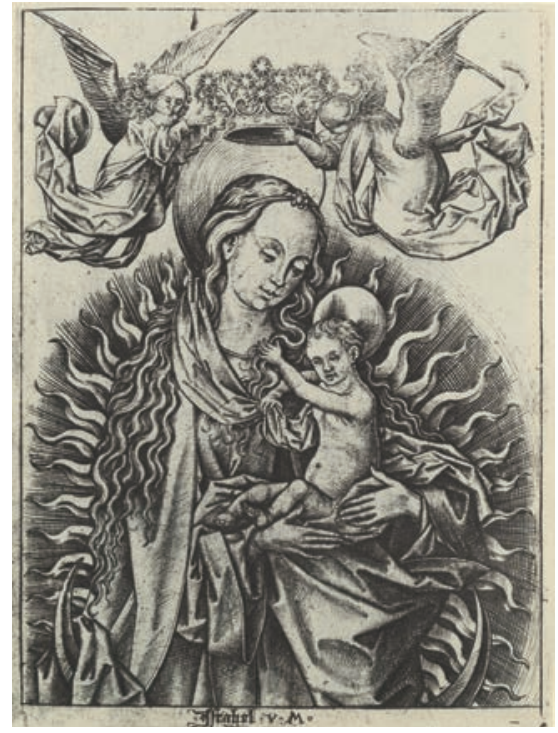

6

$\oplus$

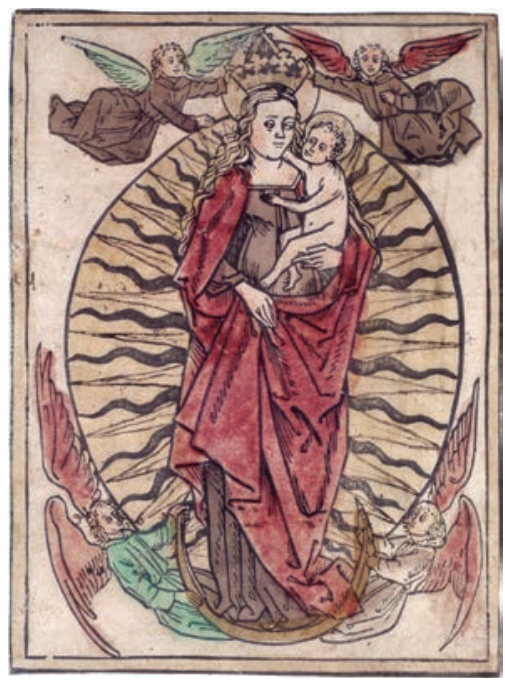

7

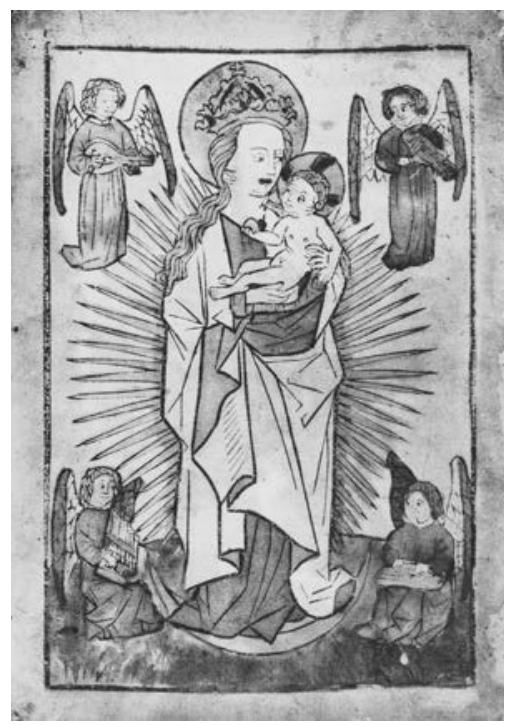

8 


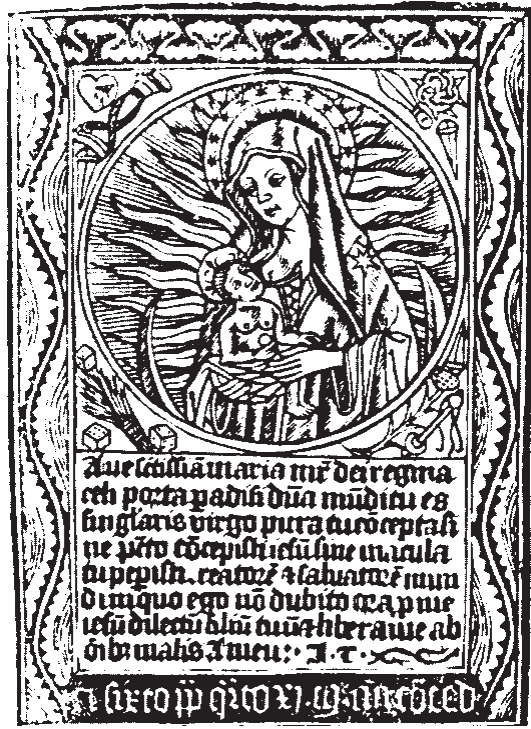

9

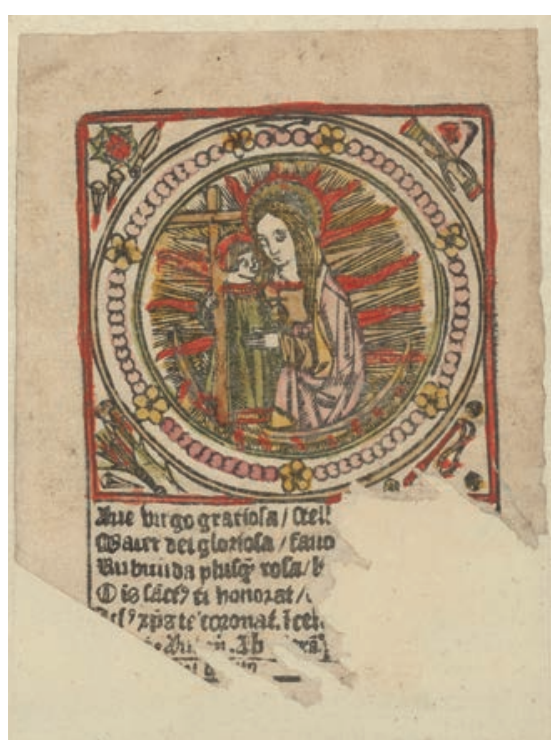

IO
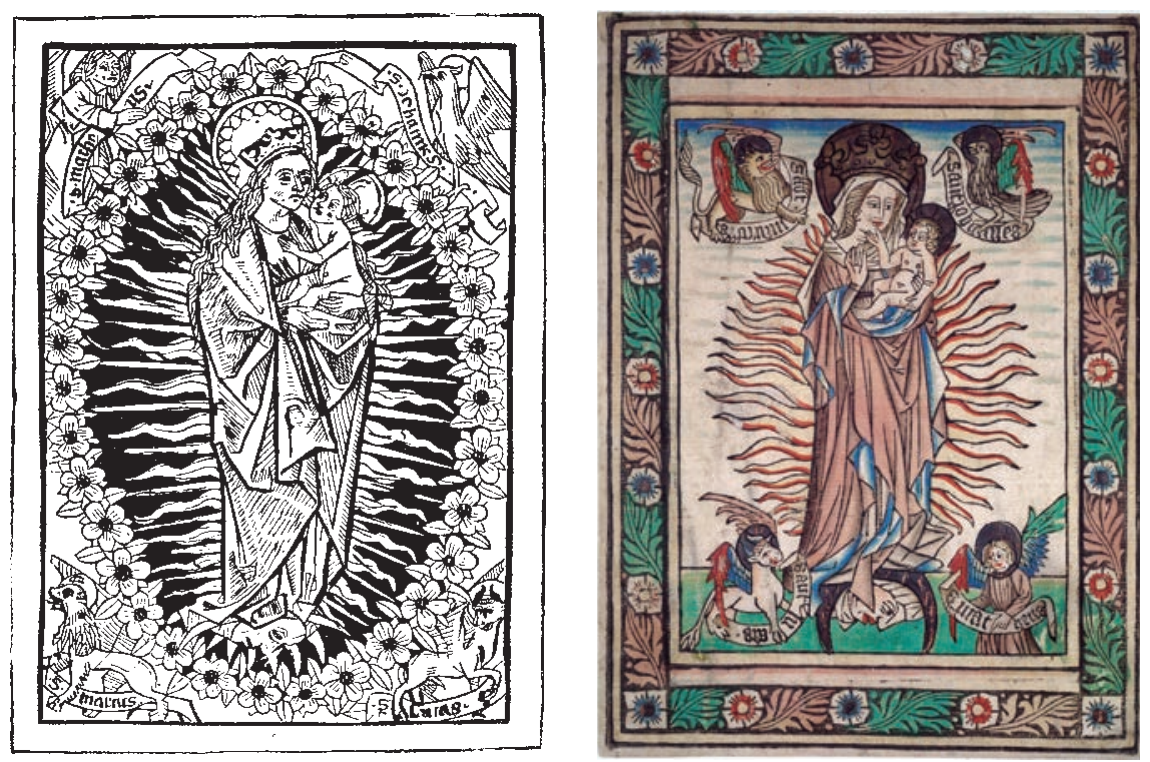

II

I2 
DOI: http://dx.doi.org/10.22201/iie.18703062e.2015.107.2558

\section{6}

GISELA VON WOBESER

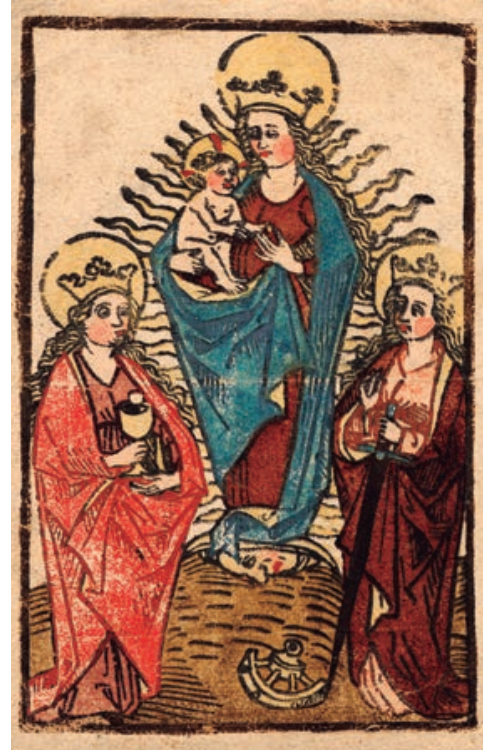

I3

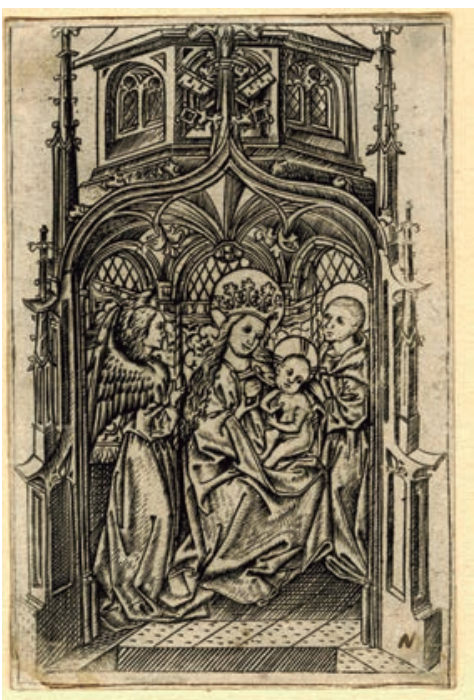

I5

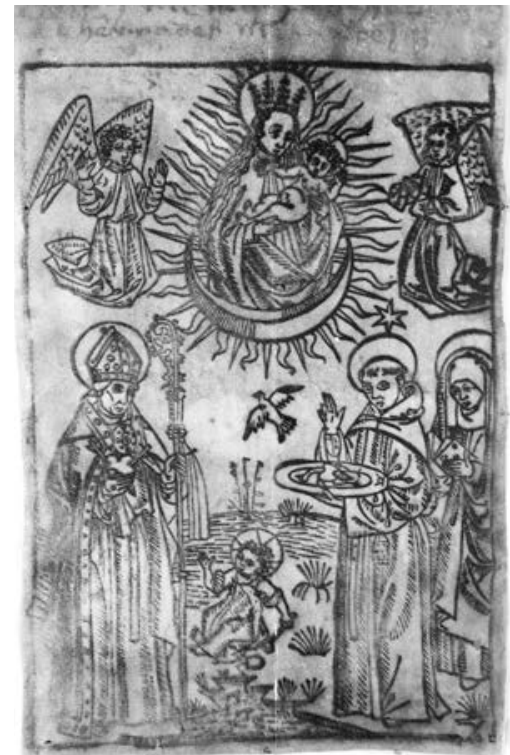

I4

$\oplus$

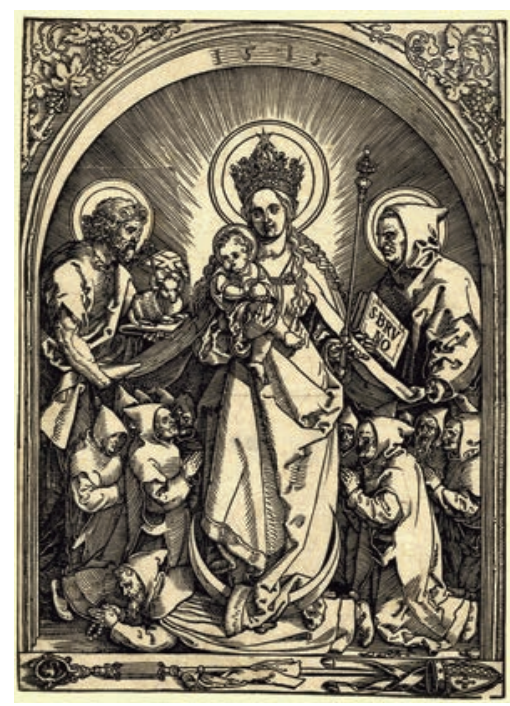

16 
DOI: http://dx.doi.org/10.22201/iie.18703062e.2015.107.2558
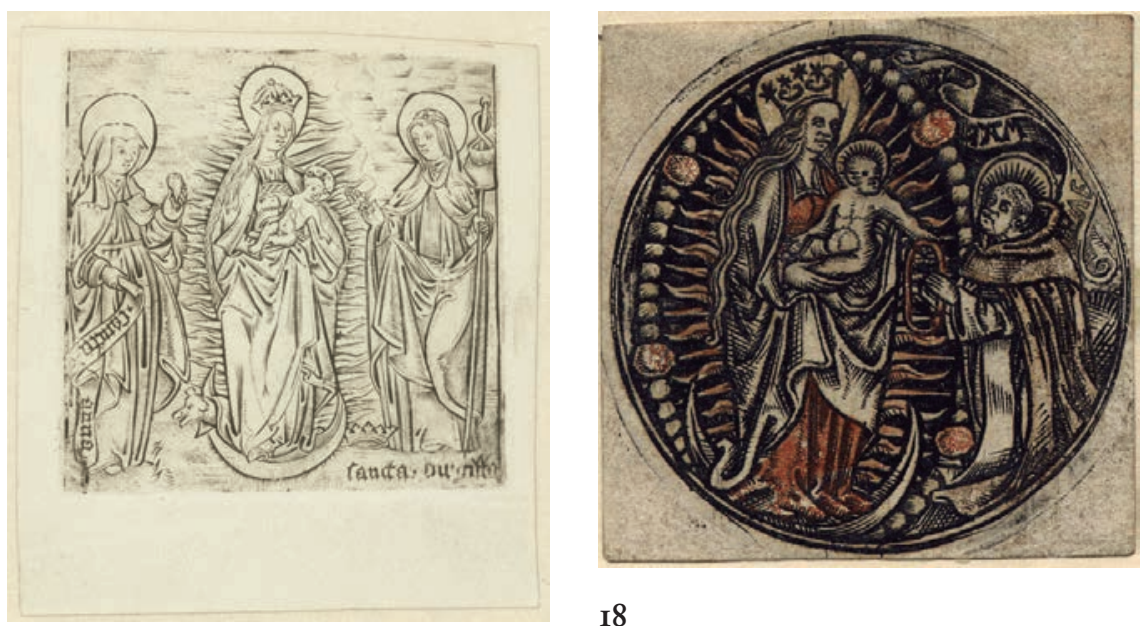

18

I7

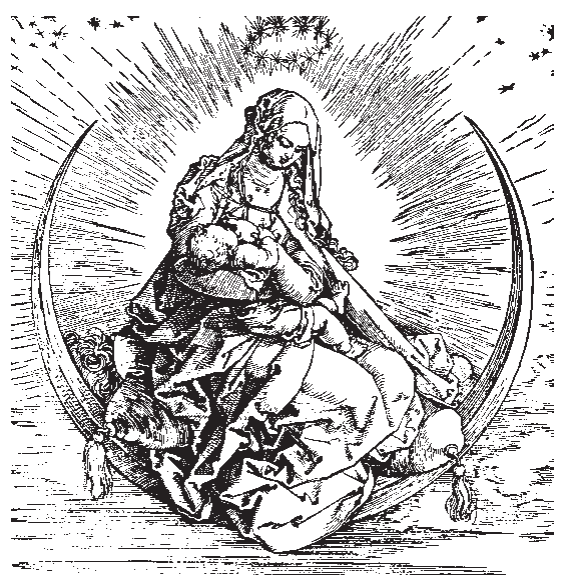

I9

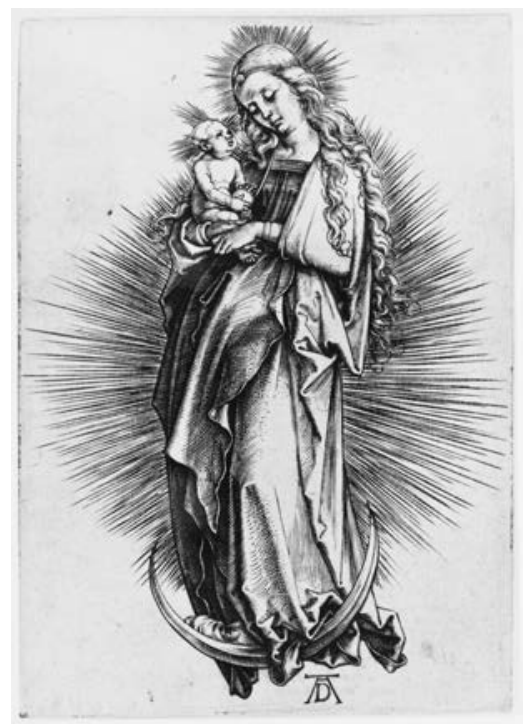




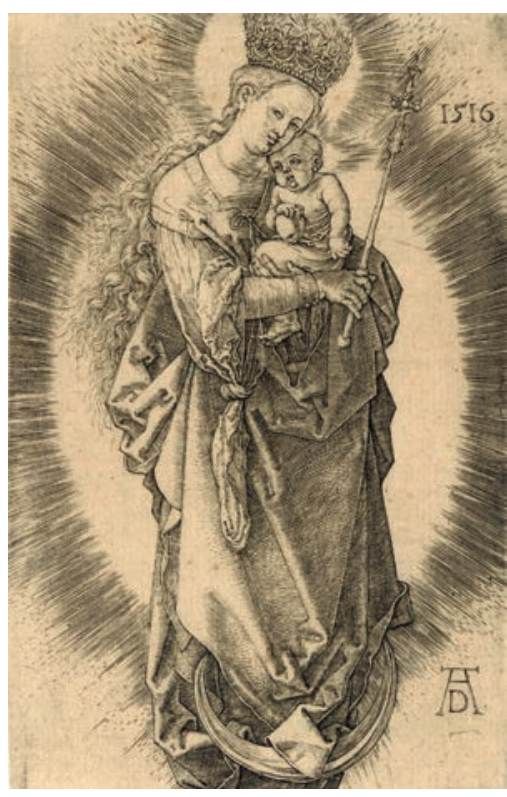

2I

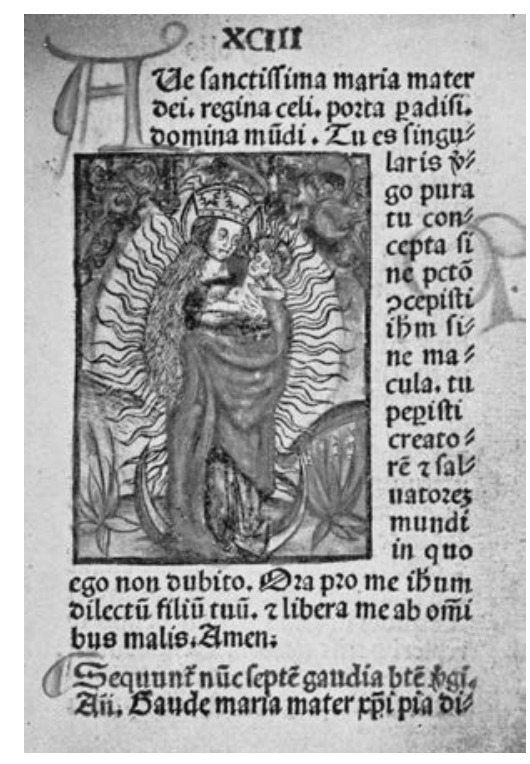

23

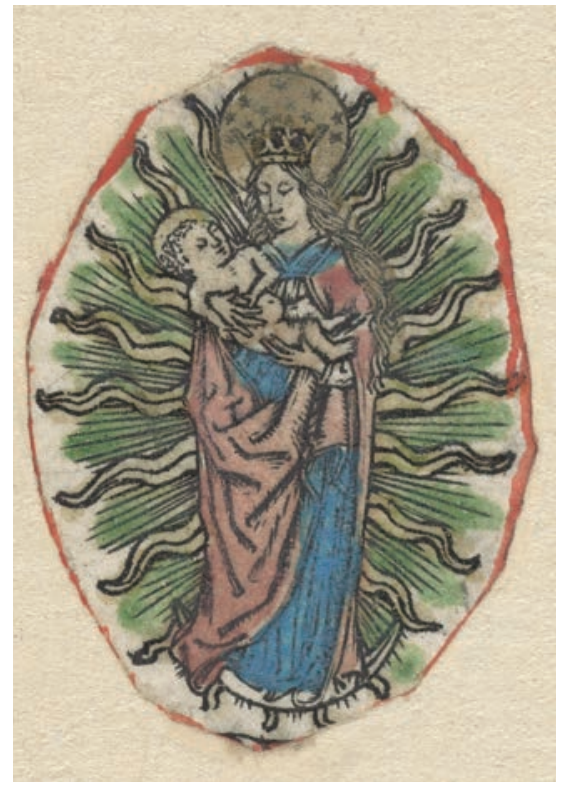

22

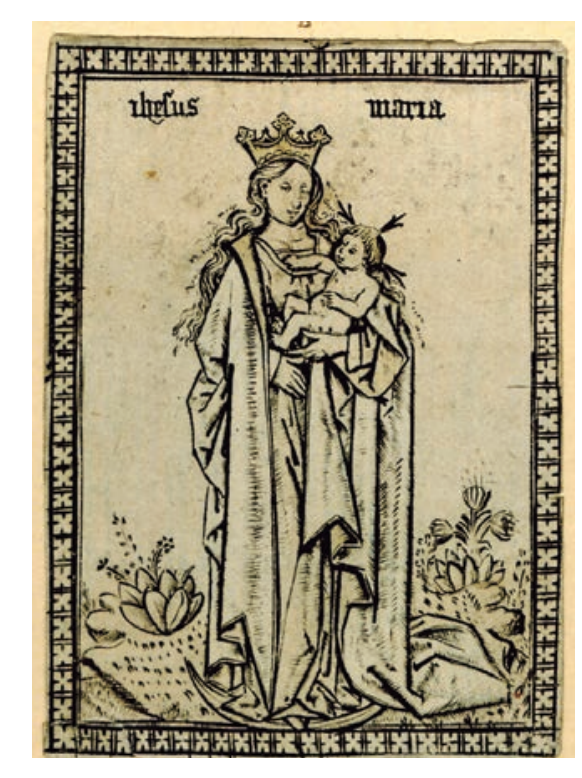

24

$\oplus$ 


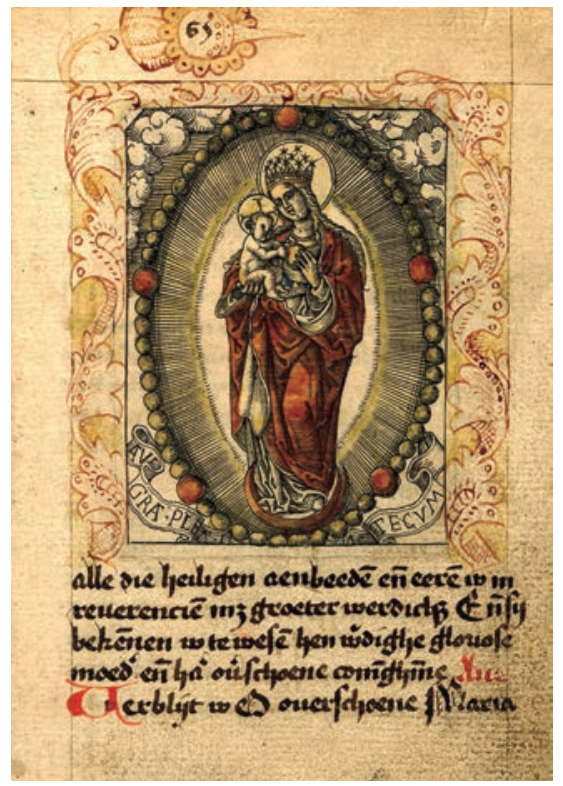

25

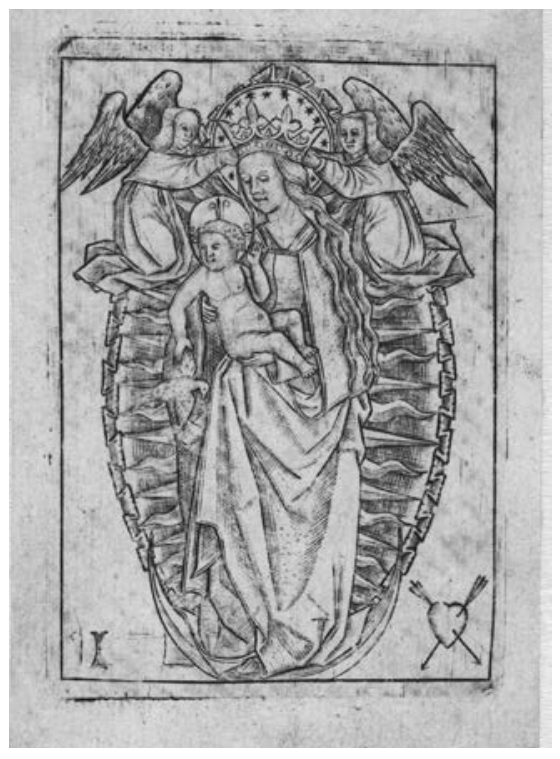

27

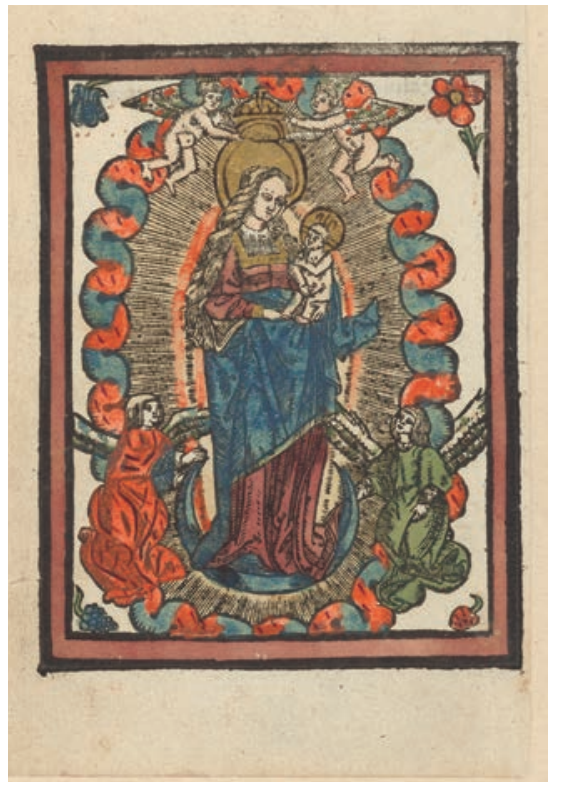

26

$\oplus$

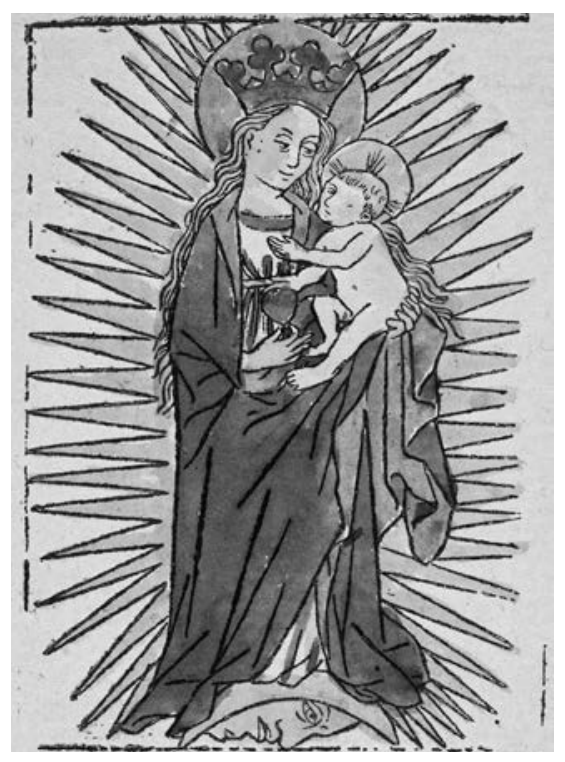

28 


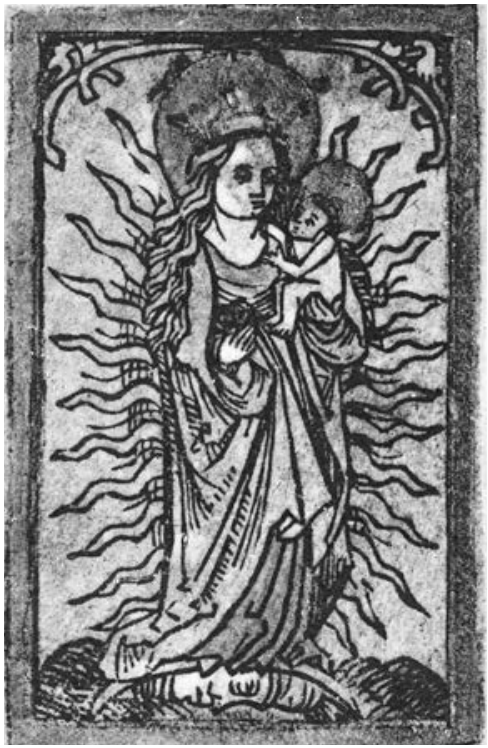

29

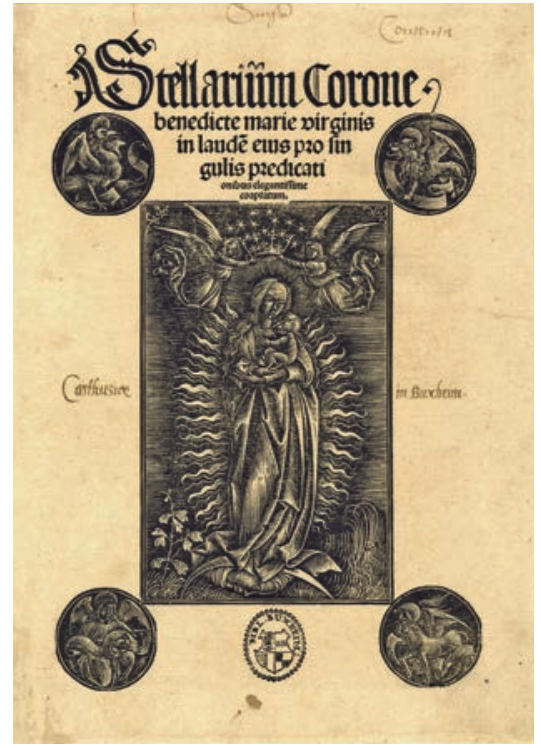

30

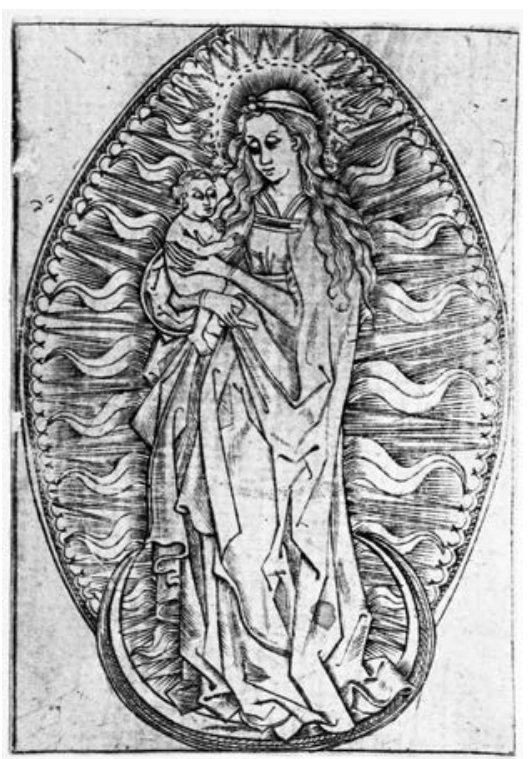

32

$\oplus$

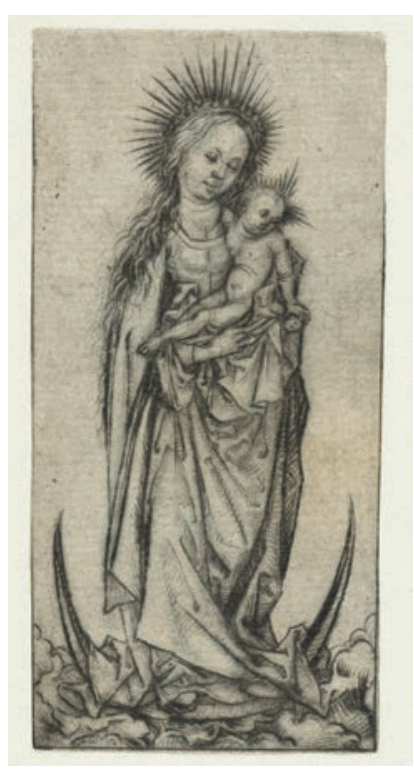

3I 


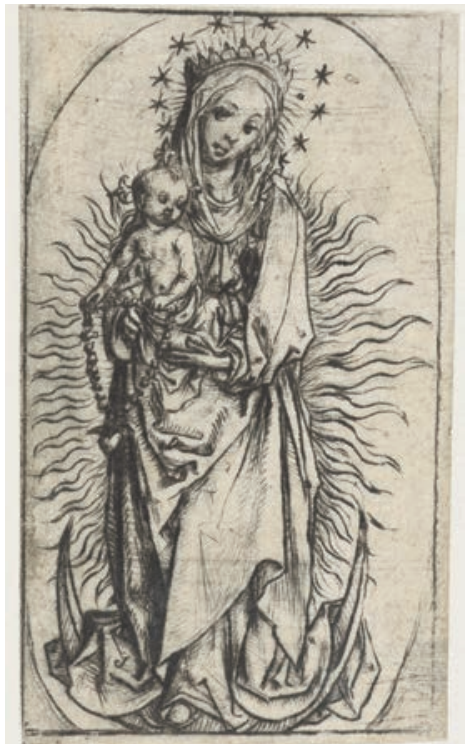

33

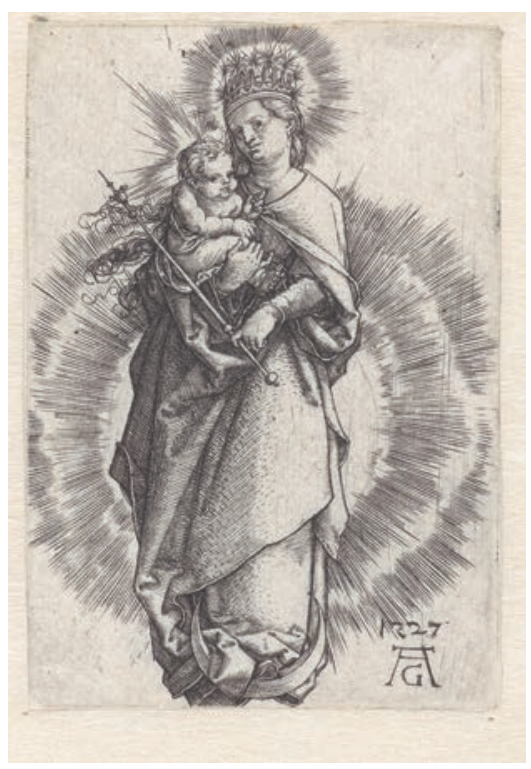

35

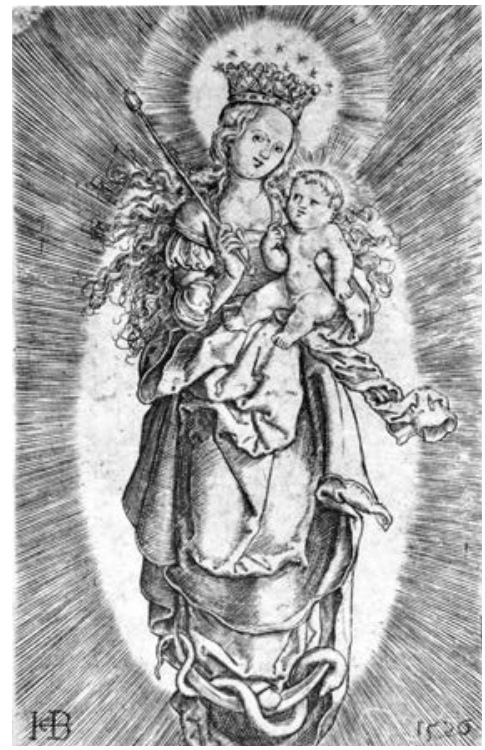

34

$\oplus$

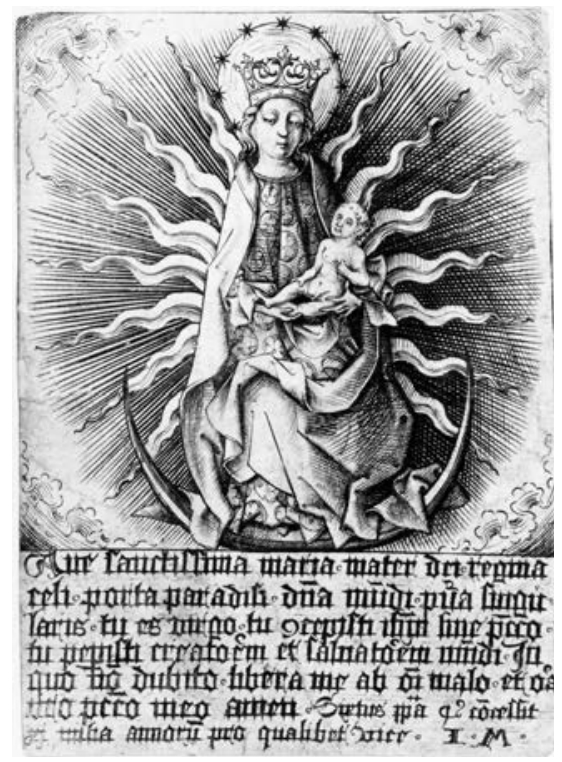

36 
DOI: http://dx.doi.org/10.22201/iie.18703062e.2015.107.2558

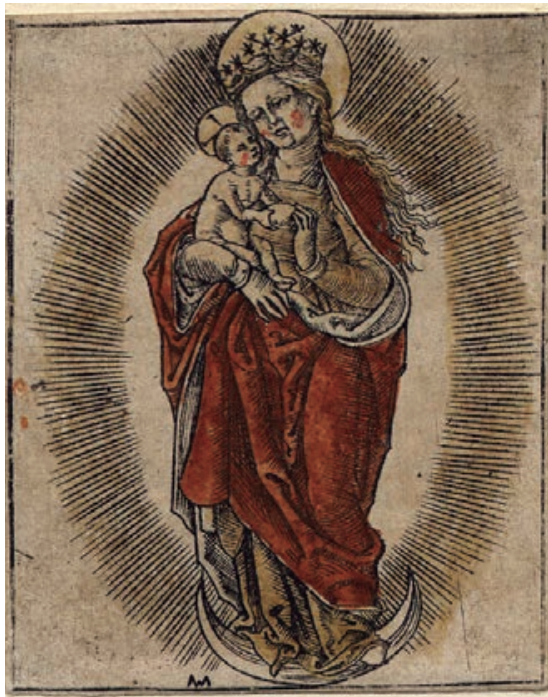

37

$\oplus$

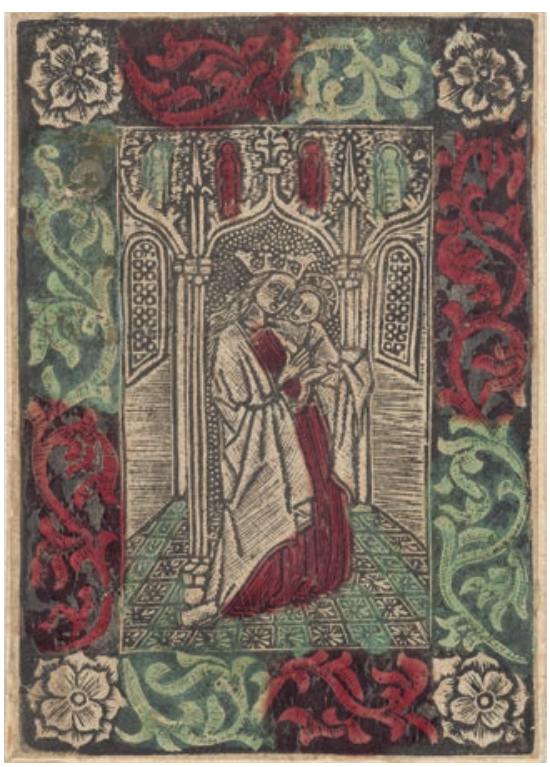

39

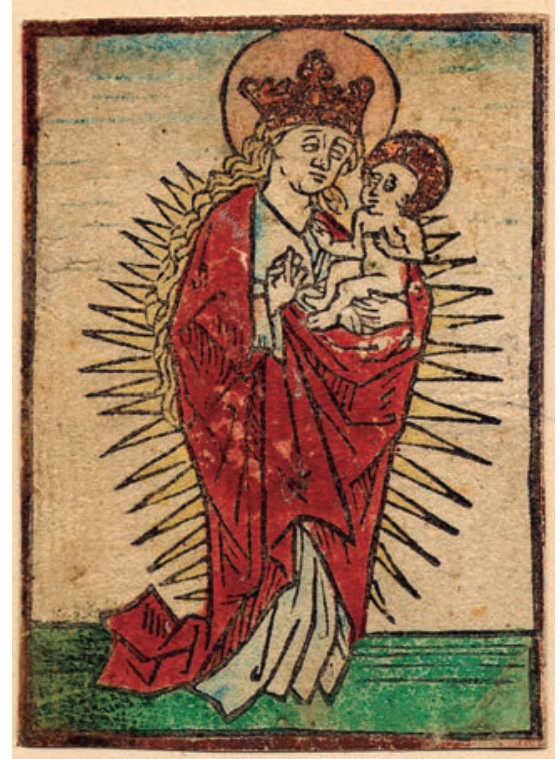

38

$\oplus$

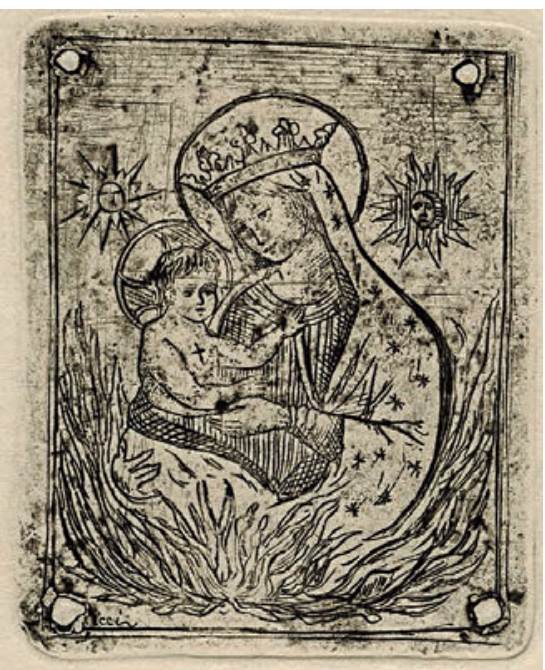

40 

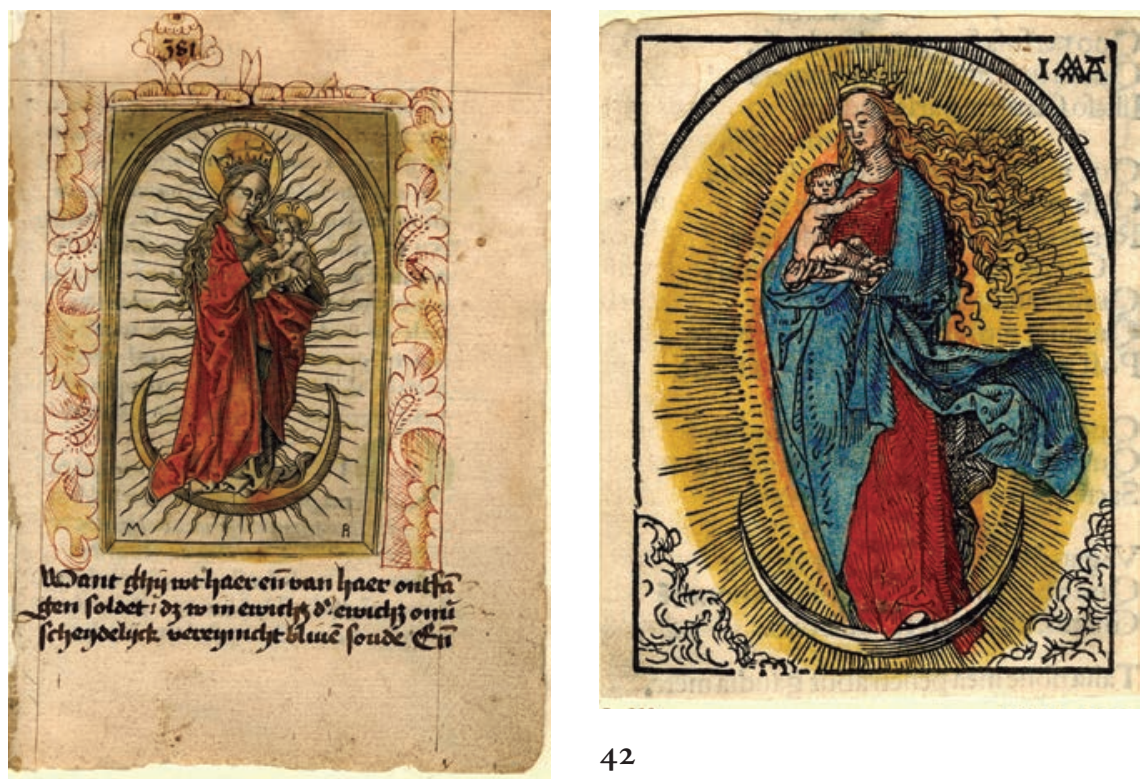

42
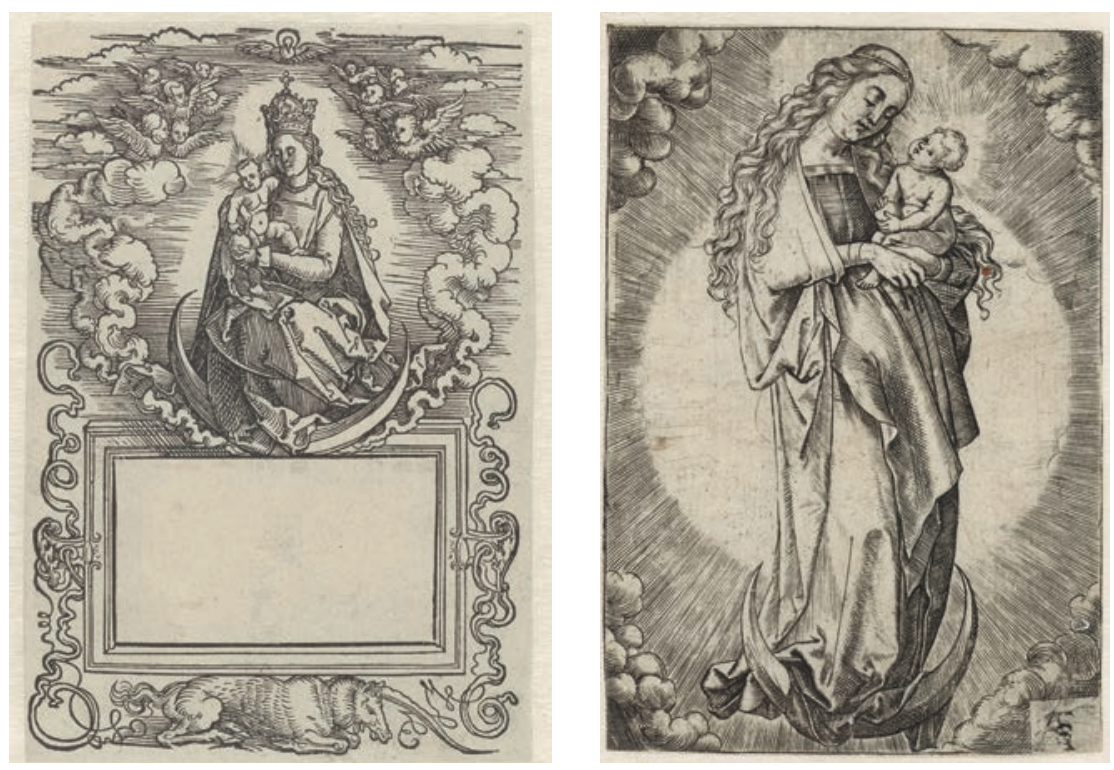
DOI: http://dx.doi.org/10.22201/iie.18703062e.2015.107.2558

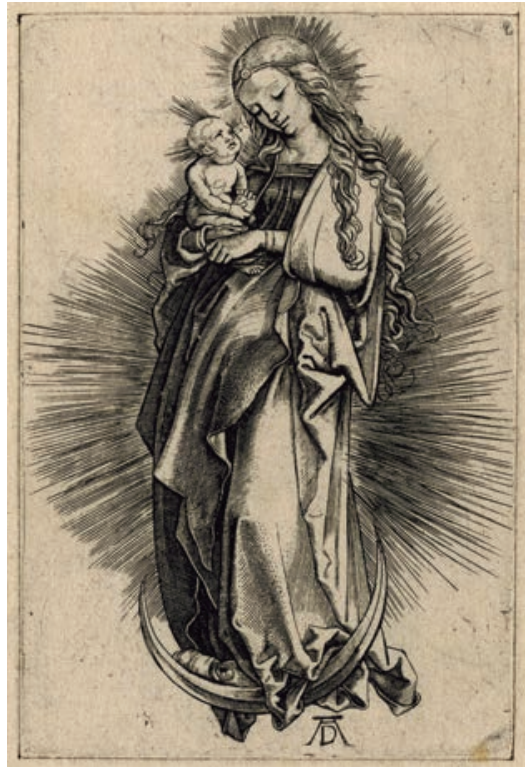

45

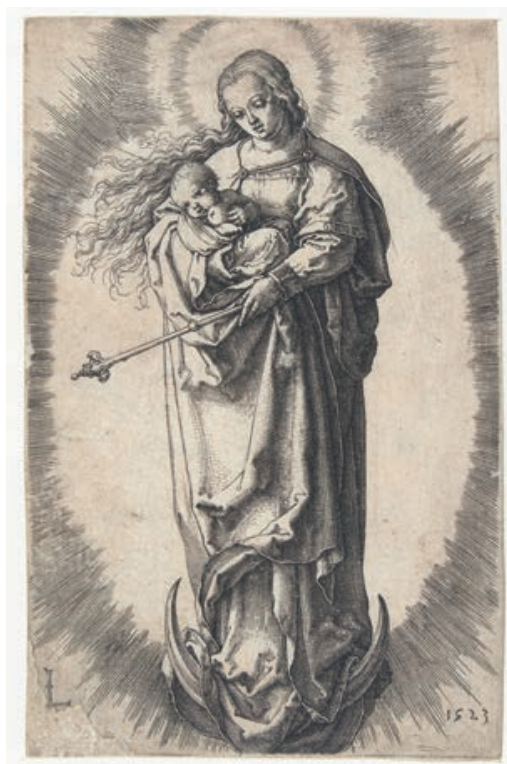

47

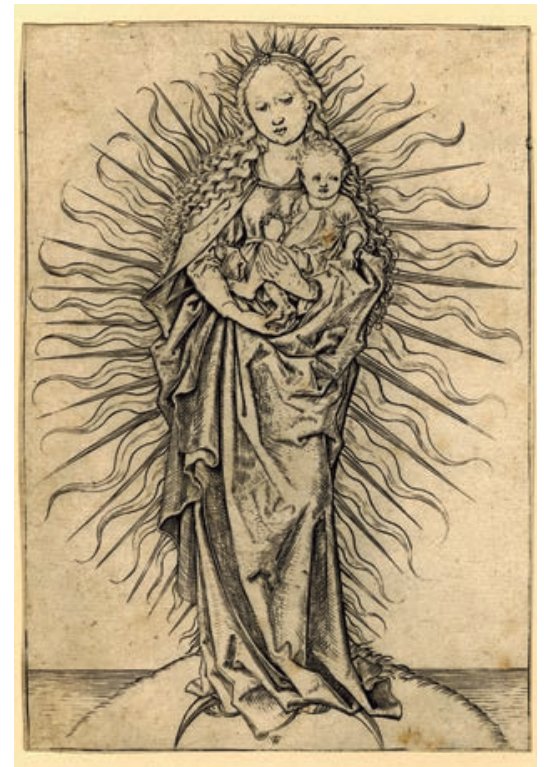

46

$\oplus$

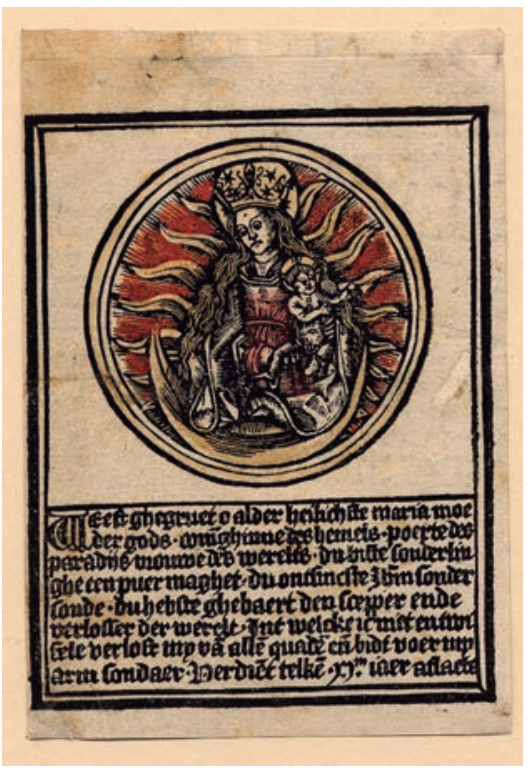

48 
DOI: http://dx.doi.org/10.22201/iie.18703062e.2015.107.2558

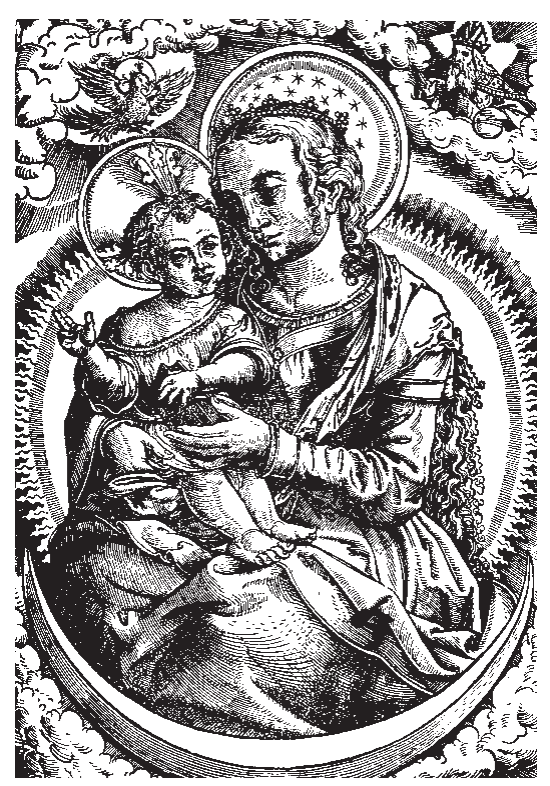

$\oplus$

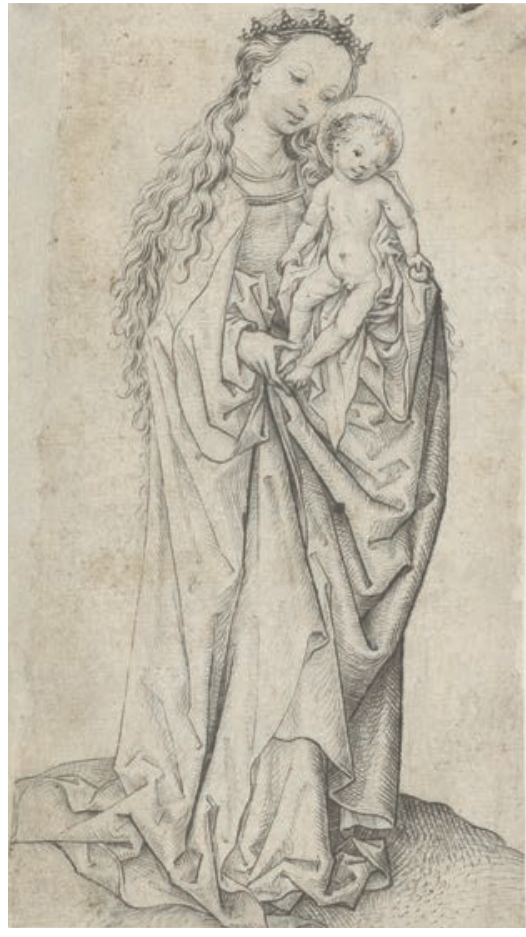

50 


\section{$\oplus$}

DOI: http://dx.doi.org/10.22201/iie.18703062e.2015.107.2558

226

GISELA VON WOBESER

$\oplus$

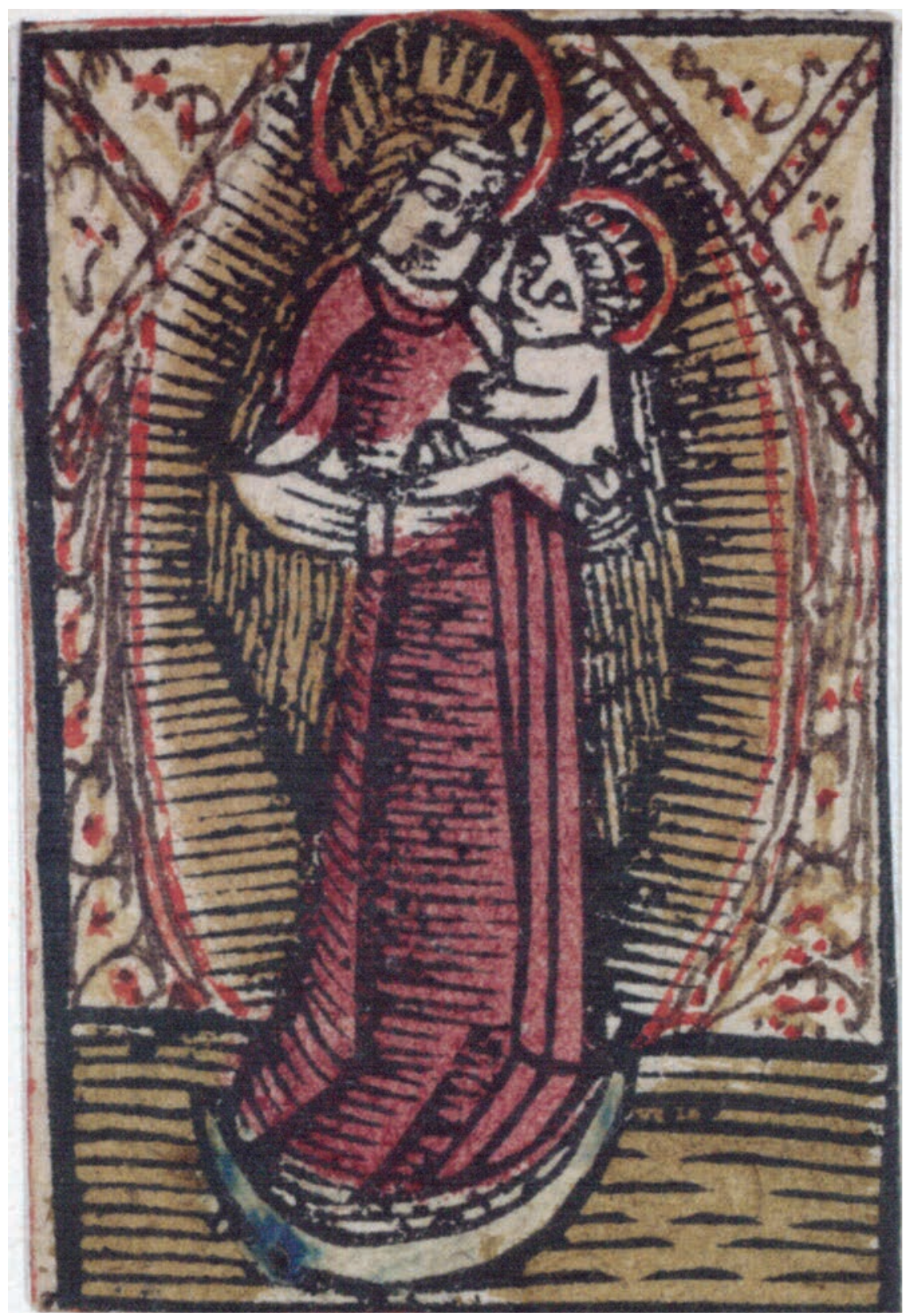




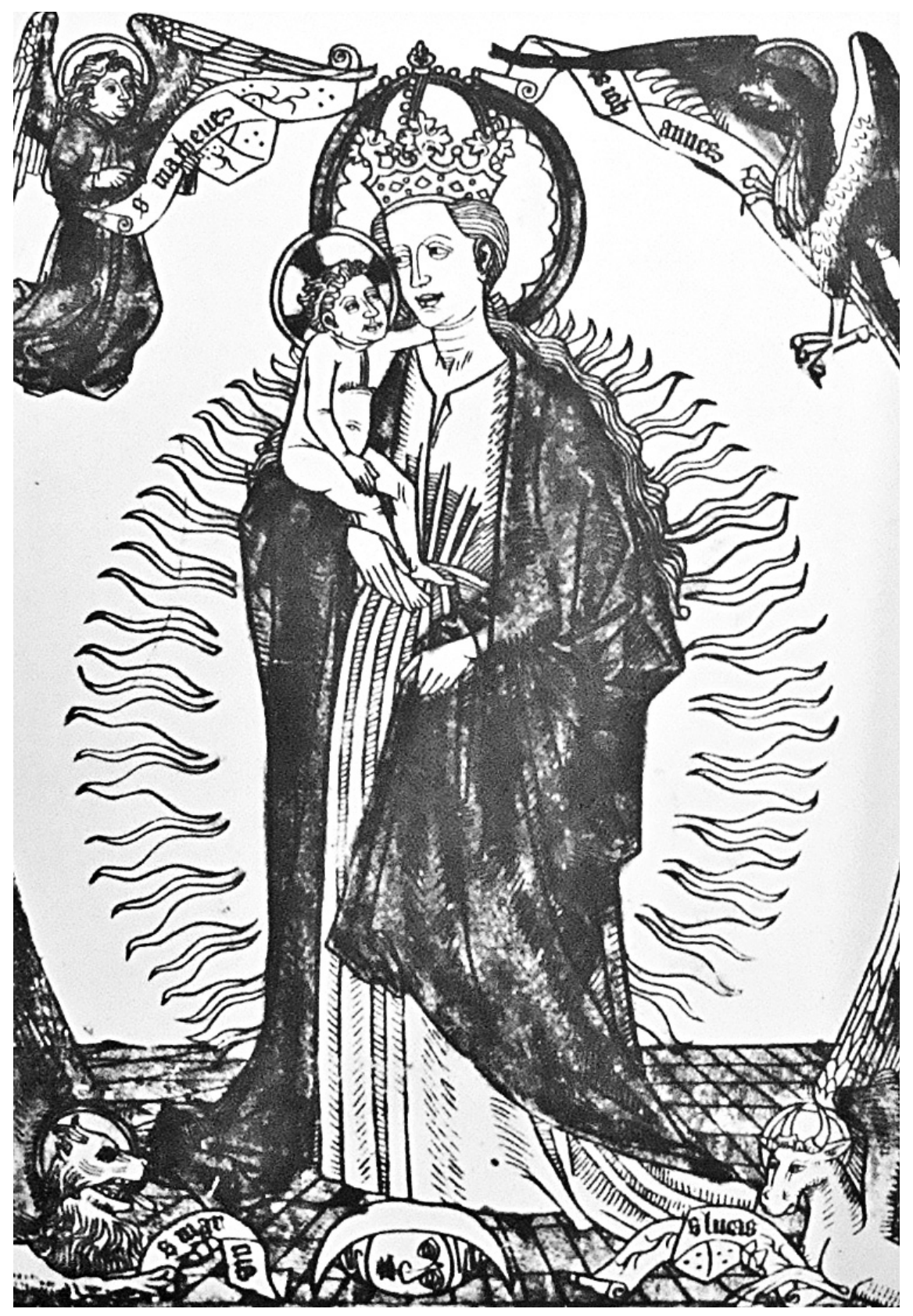

